\title{
Boceprevir and telaprevir for the treatment of chronic hepatitis $C$ genotype I infection: an indirect comparison meta-analysis
}

This article was published in the following Dove Press journal:

Therapeutics and Clinical Risk Management

7 March 2012

Number of times this article has been viewed

\author{
Curtis L Cooper' \\ Eric Druyts ${ }^{2}$ \\ Kristian Thorlund ${ }^{3}$ \\ Jean B Nachega ${ }^{4}$ \\ Antoine C El Khoury ${ }^{5}$ \\ Christopher O'Regan ${ }^{6}$ \\ Edward J Mills ${ }^{2,3}$ \\ 'Division of Infectious Diseases, \\ Faculty of Medicine, ${ }^{2}$ Faculty of \\ Health Sciences, University of Ottawa, \\ Ottawa, ${ }^{3}$ Department of Clinical \\ Epidemiology and Biostatistics, \\ McMaster University, Hamilton, \\ Ontario, Canada; ${ }^{4}$ Bloomberg School \\ of Public Health, Johns Hopkins \\ University, Baltimore, MD, ${ }^{5}$ Merck \\ and $\mathrm{Co}$, Inc, Whitehouse Station, \\ NJ, ${ }^{6}$ Merck Sharp and Dohme Ltd, \\ Hoddesdon, Hertfordshire, \\ United Kingdom
}

Correspondence: Edward J Mills Faculty of Health Sciences, University of Ottawa, 43 Templeton Street, Ottawa, Ontario KIN 6XI, Canada $\mathrm{Tel}+\mathrm{I} 7783178530$

Fax +l 6048755179

Email edward.mills@uottawa.ca
Background: The aim of this study was to examine the relative efficacy and safety of boceprevir and telaprevir, when used in combination with pegylated interferon alpha and ribavirin, using an indirect comparison meta-analysis.

Methods: Published phase II and phase III randomized placebo-controlled trials examining the efficacy of boceprevir and telaprevir in chronic hepatitis $\mathrm{C}$ virus genotype 1 infected adult populations were included. The primary outcomes were sustained virologic response, relapse, and discontinuation of all study drugs. Secondary outcomes included the adverse events of anemia, neutropenia, rash, and pruritus.

Results: Four boceprevir trials and six telaprevir trials were included. No significant differences were observed for sustained virologic response among either naïve (relative risk [RR] 1.14, 95\% confidence interval $[\mathrm{CI}] 0.93-1.37, P=0.20$ ) or experienced patients (RR $0.81,95 \% \mathrm{CI}$ $0.52-1.23, P=0.30$ ). Similarly, for relapse among naïve (RR 0.80, 95\% CI 0.18-3.45, $P=0.77$ ) and experienced patients (RR $1.71,95 \%$ CI $0.90-3.24, P=0.10)$, or discontinuation of therapy for naïve (RR 0.80, 95\% CI 0.28-2.29, $P=0.72$ ) and experienced patients (RR 0.88, 95\% CI $0.69-1.12, P=0.30)$. Telaprevir was more likely to be associated with rash and pruritus, and boceprevir was more likely to be associated with neutropenia in certain patient populations.

Conclusion: Boceprevir and telaprevir appear comparable in terms of sustained virologic response, relapse, or discontinuation of therapy for patients treated with standard-dose therapy durations and response-guided therapy durations.

Keywords: direct-acting antivirals, boceprevir, telaprevir, hepatitis C, meta-analysis

\section{Background}

Two direct-acting antiviral compounds, boceprevir and telaprevir, have recently been approved by drug regulatory boards in North America and Europe to treat adults with chronic hepatitis $\mathrm{C}$ virus genotype 1 infection. ${ }^{1-3}$ Boceprevir and telaprevir prevent hepatitis $\mathrm{C}$ viral replication by inhibiting the activity of protease NS3/4A. ${ }^{4}$ Clinical trials demonstrate that boceprevir or telaprevir in combination with pegylated interferon (peginterferon) alpha and ribavirin dramatically improve treatment efficacy in both treatment-naïve patients (those who have not received any drug therapy for their hepatitis $\mathrm{C}$ virus infection) $)^{5-10}$ and treatment-experienced patients (those who have previously been treated for hepatitis $\mathrm{C}$ virus and did not achieve a sustained virologic response to the therapy), ${ }^{11-14}$ when compared to conventional peginterferon alpha and ribavirin therapy. Currently, there is no direct evidence to establish if boceprevir or telaprevir offer therapeutic advantages over one another. To this end, the relative efficacy and safety of boceprevir and telaprevir, when used in combination with peginterferon 
alpha and ribavirin, were examined using a direct and indirect meta-analysis of the currently published evidence.

\section{Methods}

\section{Eligibility criteria}

Published phase II or phase III randomized placebo-controlled trials examining the efficacy and safety of boceprevir and telaprevir in hepatitis $\mathrm{C}$ virus genotype 1 infected adult populations were included. Trials had to include these directacting drugs in addition to peginterferon alpha and ribavirin. No limitation on treatment duration was set. Therefore, trials could include standard dose-duration regimens (where boceprevir is provided in weeks 4-48 of a 48-week treatment duration or telaprevir is provided in weeks 1-12 of a 48-week treatment duration), response-guided therapy regimens, and any other treatment dose-duration regimens. Both treatmentnaïve and treatment-experienced populations were included. Trials that reported only on dosing strategies of the individual drugs without a comparison to a control were excluded.

\section{Search strategy}

In consultation with a medical librarian, a systematic search of the literature was conducted. Two broad and sensitive searches were conducted, one including only the term "boceprevir," the other including only the term "telaprevir." Each search was limited to clinical trials in humans. Searches were not limited by language, sex, or age. Two investigators (EM, ED) independently searched each of the following ten databases (from inception to week 40 [October 3-9, 2011]): MEDLINE, Embase, Cochrane Central Register of Controlled Trials, AMED, CINAHL, TOXNET, Development and Reproductive Toxicology, Hazardous Substances Data Bank, PsycINFO, and Web of Science. The bibliographies of published systematic and narrative reviews and relevant included trials were also searched. Where necessary, industry was also contacted for assistance in identifying completed clinical trials.

\section{Study selection}

Two investigators (EM, ED) working independently, in duplicate, scanned all abstracts and obtained the full text reports of records indicating that the study was a randomized placebo-controlled trial that examined the efficacy and safety of boceprevir or telaprevir in adult populations. After obtaining full reports of the candidate studies, the same reviewers independently assessed eligibility via full text review. Where required, a third clinician reviewer (CC) provided arbitration.

\section{Data abstraction and endpoints}

Two investigators (EM, ED) working independently, in duplicate, abstracted data on the primary outcomes of interest: the proportion of patients achieving sustained virologic response (defined as an undetectable hepatitis $\mathrm{C}$ virus ribonucleic acid [RNA] at the end of the 24-week post therapy follow-up period), the proportion of patients relapsing (defined as a reoccurrence of hepatitis C virus RNA within the 24-week post therapy follow-up period), and the proportion of patients discontinuing treatment (defined as the discontinuation of all assigned study drugs during the set treatment period).

Outcomes data were extracted for both treatment-naïve patients (generally defined as patients with no exposure to peginterferon alpha plus ribavirin) and treatmentexperienced patients (generally defined as patients with prior exposure to peginterferon alpha plus ribavirin), and the subgroups of patients with compensated cirrhosis, prior relapse (generally defined as patients who had a full decrease in hepatitis $\mathrm{C}$ viral load after peginterferon alpha plus ribavirin treatment, but a subsequent reoccurrence of the virus during the 24-week follow-up period after the end of treatment), and prior nonresponse (generally defined as patients who did not achieve a decrease in hepatitis $\mathrm{C}$ viral load during peginterferon alpha plus ribavirin treatment or a partial decrease in hepatitis $\mathrm{C}$ viral load during peginterferon alpha plus ribavirin treatment). Data was also abstracted for commonly reported adverse events: anemia (generally defined as hemoglobin less than $100 \mathrm{~g} / \mathrm{L}$ ), neutropenia (generally defined as absolute neutrophil count less than $0.7510^{9} / \mathrm{L}$ ), rash (any, as reported by site investigators), and pruritus (any, as reported by site investigators). Furthermore, trial characteristics (ie, interventions, treatment doses, treatment durations) and participant baseline characteristics (ie, age, sex, genosubtype) were abstracted.

\section{Data analysis}

In order to assess interrater reliability on inclusion of articles, the phi statistic was calculated, which was first developed to provide a measure of interobserver agreement independent of chance. ${ }^{15}$ Pairwise meta-analysis of all trial evidence using a DerSimonian-Laird random effects model, which recognizes and anchors studies as a sample of all potential studies, and incorporates an additional between-study component to the estimate of variability, thus placing additional weighting on the smaller studies. ${ }^{16,17}$ When more than two trial arms could be pooled, heterogeneity in the pairwise estimates was assessed using the $\mathrm{I}^{2}$ statistic as a measure of the proportion of the overall variation that is attributable to between-study 
heterogeneity..$^{18}$ As there were no direct (head-to-head) evaluations of boceprevir versus telaprevir, the adjusted indirect comparison statistic, first described by Bucher et al, ${ }^{19}$ was used. The adjusted indirect comparison utilized the evidence on boceprevir versus peginterferon plus ribavirin and the evidence on telaprevir versus peginterferon plus ribavirin to produce an estimate of comparative effectiveness between boceprevir and telaprevir. Meta-regression analysis of the indirect evidence was performed to explore whether the results from the indirect comparisons were robust to changes in the two trial baseline characteristics, type of peginterferon given (alpha-2a [peg-2a] or alpha-2b [peg-2b]), and treatment experience (naïve or experienced). Peginterferon type and treatment experience were included in the model for the primary meta-regression and each of the two covariates alone was included as a sensitivity analysis. For all analyses, relative risk was used as the primary effect estimate with $95 \%$ confidence intervals (CIs) for each.

As a sensitivity analysis, a Bayesian multiple treatment meta-analysis was applied. ${ }^{20}$ For treatment-naïve patients, four trials from a previous review ${ }^{21}$ that compared peg-2a with peg- $2 b$ were identified. To control for the fact that telaprevir had only been compared to peg-2a and boceprevir had only been compared to peg- $2 b$ among treatment-naïve patients, the comparison of peg- $2 a$ versus peg- $2 b$ was additionally included in the treatment network and a conventional random-effects multiple treatment comparison was carried out. For treatment-experienced patients, only one trial from $a$ previous review that compared peg- $2 a$ with peg- $2 b$ was identified. ${ }^{21}$ With only one trial informing this comparison, and only one trial informing telaprevir versus peg-2a, it was not possible to run a Bayesian multiple treatment comparison. Therefore, a conventional frequentist adjusted indirect comparison including the peg- $2 \mathrm{a}$ versus peg- $2 \mathrm{~b}$ comparison was performed.

The main analyses considered the three outcomes: sustained virologic response, relapse, and treatment discontinuation. The subgroup analyses used the same outcomes, where possible, but were restricted first to cirrhotic patients and then second to prior relapse and prior nonresponders. The adverse events analyses included anemia, neutropenia, rash, and pruritus as outcomes. Each analysis was conducted among two experimental settings: standard-dose duration (where boceprevir is provided in weeks 4-48 of a 48-week treatment duration or telaprevir is provided in weeks $1-12$ of a 48 -week treatment duration) and response-guided therapy, and was analyzed separately for treatment-naïve and treatment-experienced patients, with the exception of prior relapse and prior nonresponse patients who were all treatment-experienced. As a sensitivity analysis for the main analyses, all available boceprevir arms and telaprevir arms among naïve or experienced groups were examined. Analyses were conducted using StatsDirect version 2.5.2 (StatsDirect Ltd, Cheshire, United Kingdom) and $\mathrm{R}$ version 2.12.2.22

\section{Results Included studies}

Ten published phase II and III randomized placebo-controlled trials provided efficacy and safety data among 5072 patients treated with boceprevir or telaprevir in combination with peginterferon alpha plus ribavirin. Interobserver agreement was very good (phi $=0.91)$. Four of the trials provided data among those treated with boceprevir and peginterferon alpha plus ribavirin combinations ${ }^{5,6,11,12}$ (two of these trials were conducted in treatment-naïve populations ${ }^{5,6}$ and two were conducted in treatment-experienced populations ${ }^{11,12}$ ) and six of the trials provided data among those treated with telaprevir and peginterferon alpha plus ribavirin combinations ${ }^{7-10,13,14}$ (four of these trials were conducted in treatment-naïve populations ${ }^{7-10}$ and two were conducted in treatment-experienced populations ${ }^{13,14}$ ). Tables 1 and 2 provide the characteristics of these included trials. The populations were effectively comparable in terms of age, gender, and race. In terms of genosubtype, Kumada et a $1{ }^{10}$ was an exception with a population that was predominantly genosubtype $1 \mathrm{~b}$; genosubtype 1a was most common among the populations recruited in all other trials. Fifteen trials identified in the search were excluded because they analyzed data from phase I trials, ${ }^{23-34}$ or they were not placebo-controlled. ${ }^{35,36}$ Figure 1 shows a schematic of the study selection process.

\section{Standard dose-duration boceprevir or telaprevir among all patients}

All four randomized placebo-controlled boceprevir trials (two conducted among treatment-naïve patients and two conducted among treatment-experienced patients) included standard dose-duration trial arms, ${ }^{5,6,11,12}$ and three randomized placebo-controlled telaprevir trials (two conducted among treatment-naïve patients and one conducted among treatment-experienced patients) included standard doseduration trial arms. ${ }^{8,9,14}$

Tables 3 and 4 show the results of the direct comparison between standard dose-duration regimens of telaprevir or boceprevir coadministered with peginterferon alpha plus ribavirin (intervention) and placebo coadministered with 


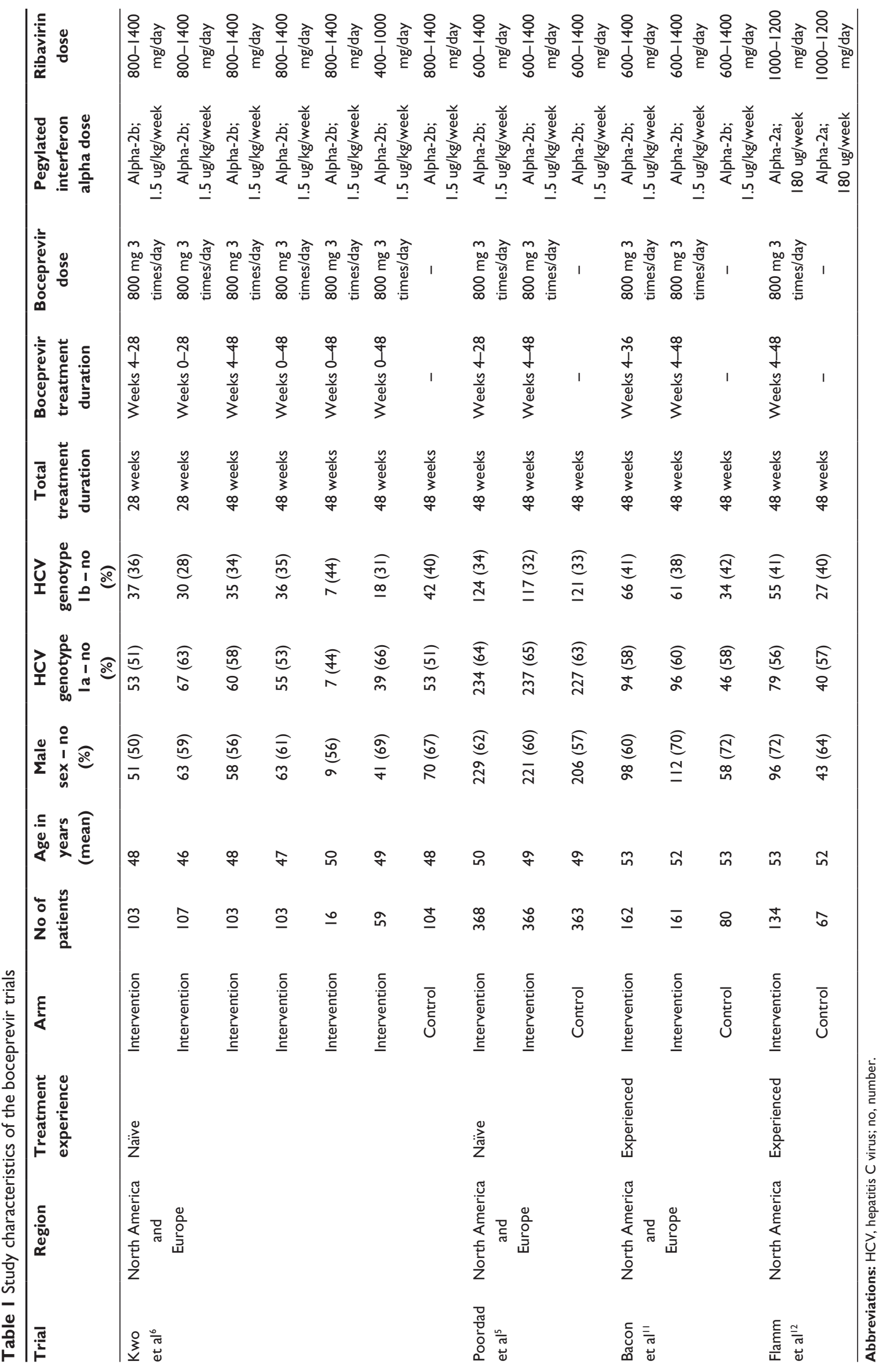




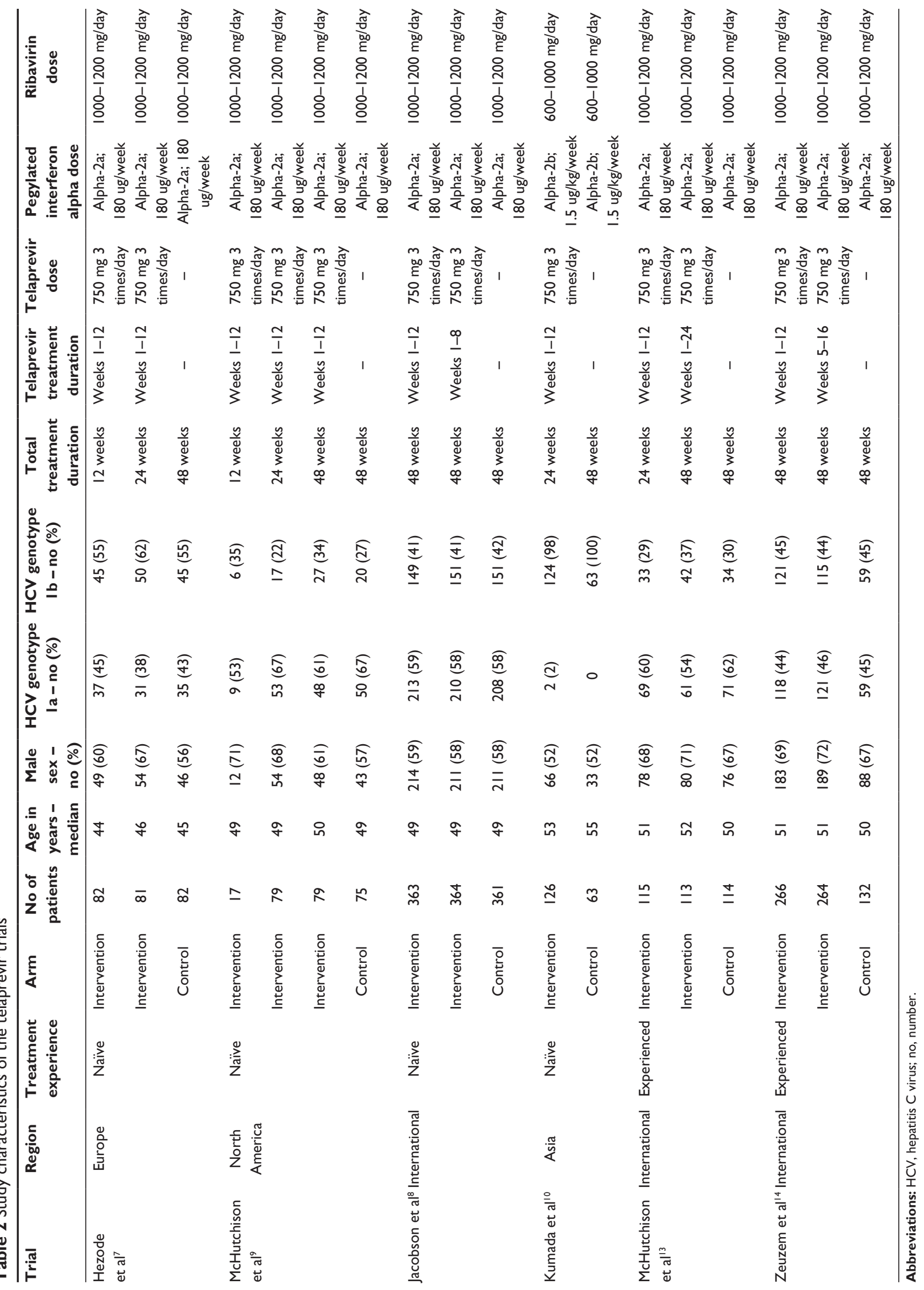




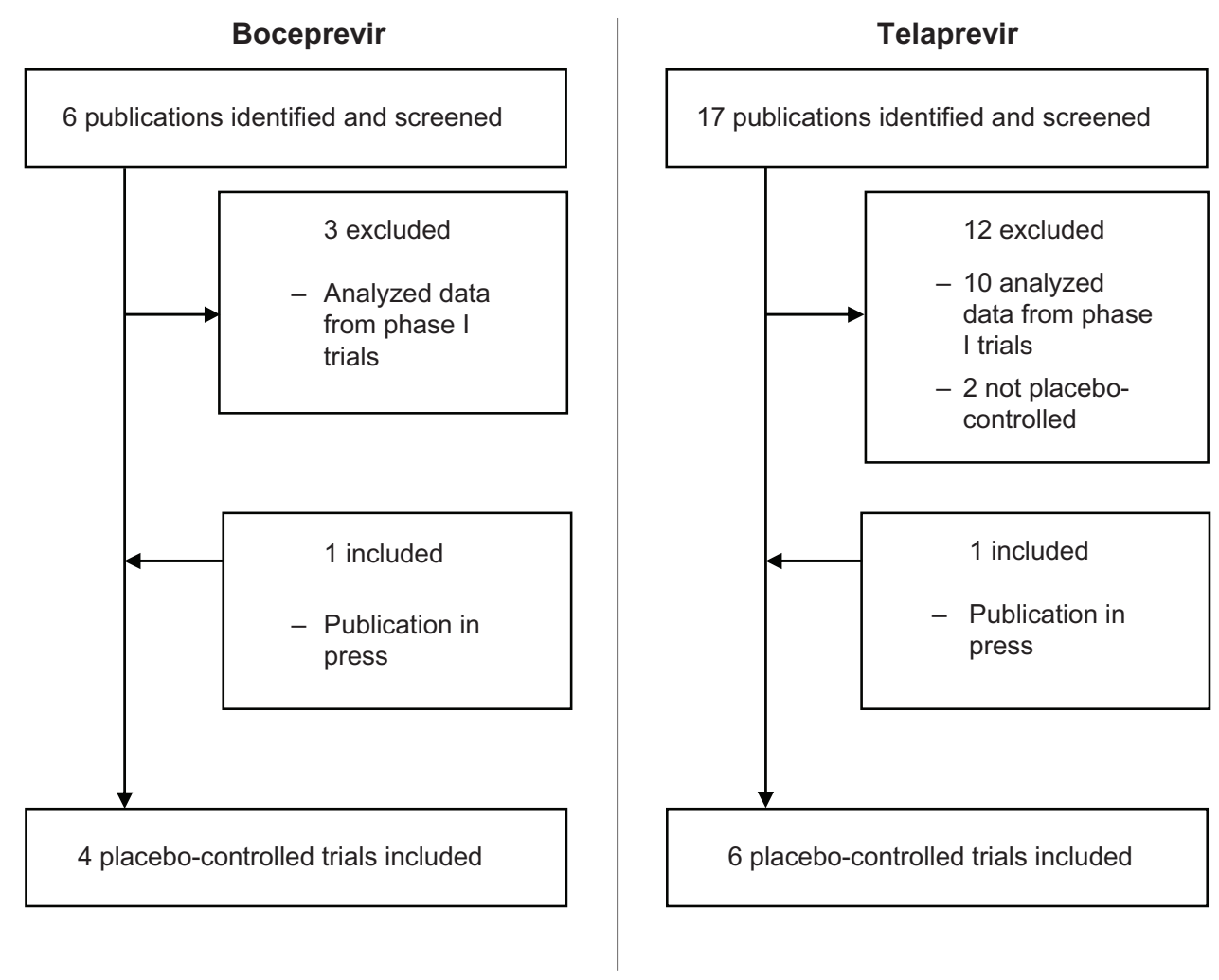

Figure I Study flow diagram.

Table 3 Direct comparison of the proportion of patients achieving a sustained virologic response, relapsing to treatment, or discontinuing treatment in the trial intervention (boceprevir provided at a dose of $800 \mathrm{mg}$ three times per day during weeks 4-48 of a 48-week treatment course and coadministered with pegylated interferon alpha plus ribavirin) and the trial control (matched placebo coadministered with pegylated interferon alpha plus ribavirin for 48 weeks)

\begin{tabular}{|c|c|c|c|c|c|}
\hline \multirow[t]{2}{*}{ Trial } & \multicolumn{2}{|c|}{ Intervention } & \multicolumn{2}{|c|}{ Control } & \multirow{2}{*}{$\begin{array}{l}\text { Relative risk } \\
\qquad(95 \% \mathrm{Cl})\end{array}$} \\
\hline & $\mathbf{N}$ & $\begin{array}{l}\text { Pooled } \\
(95 \% \mathrm{CI})\end{array}$ & $\mathbf{N}$ & $\begin{array}{l}\text { Pooled } \\
(95 \% \mathrm{Cl})\end{array}$ & \\
\hline \multicolumn{6}{|c|}{ Sustained virologic response } \\
\hline \multicolumn{6}{|l|}{ Naïve patients } \\
\hline Kwo et $\mathrm{al}^{6}$ & $77 / 103$ & \multirow{2}{*}{$70 \%(61 \%-77 \%)$} & $39 / 104$ & \multirow{2}{*}{$38 \%(33 \%-42 \%)$} & \multirow{2}{*}{$1.91(1.65-2.21)$} \\
\hline Poordad et $\mathrm{al}^{5}$ & $242 / 366$ & & $137 / 363$ & & \\
\hline \multicolumn{6}{|c|}{ Experienced patients } \\
\hline Bacon et al" & $107 / 161$ & \multirow{2}{*}{$65 \%(60 \%-71 \%)$} & $17 / 80$ & \multirow{2}{*}{$21 \%(15 \%-28 \%)$} & \multirow{2}{*}{$3.09(2.24-4.28)$} \\
\hline Flamm et al ${ }^{12}$ & $86 / 134$ & & $14 / 67$ & & \\
\hline \multicolumn{6}{|l|}{ Relapse } \\
\hline \multicolumn{6}{|l|}{ Naïve patients } \\
\hline Kwo et $\mathrm{al}^{6}$ & $2 / 81$ & \multirow{2}{*}{$6 \%(1 \%-14 \%)$} & $12 / 53$ & \multirow{2}{*}{$23 \%(17 \%-28 \%)$} & \multirow{2}{*}{$0.24(0.06-1.00)$} \\
\hline Poordad et al $\left.\right|^{5}$ & $24 / 265$ & & $39 / 176$ & & \\
\hline \multicolumn{6}{|c|}{ Experienced patients } \\
\hline Bacon et al" & $|4 /| 2 \mid$ & \multirow{2}{*}{$12 \%(8 \%-17 \%)$} & $8 / 25$ & \multirow{2}{*}{$33 \%(21 \%-47 \%)$} & \multirow{2}{*}{$0.36(0.20-0.62)$} \\
\hline Flamm et al ${ }^{12}$ & $11 / 95$ & & $7 / 21$ & & \\
\hline \multicolumn{6}{|l|}{ Discontinuation } \\
\hline \multicolumn{6}{|l|}{ Naïve patients } \\
\hline Kwo et $\mathrm{al}^{6}$ & $27 / 103$ & \multirow{2}{*}{$34 \%(21 \%-49 \%)$} & $52 / 104$ & \multirow{2}{*}{$54 \%(49 \%-60 \%)$} & \multirow{2}{*}{$0.65(0.47-0.89)$} \\
\hline Poordad et $\mathrm{al}^{5}$ & $151 / 366$ & & $204 / 363$ & & \\
\hline \multicolumn{6}{|c|}{ Experienced patients } \\
\hline Bacon et al" & $55 /|6|$ & \multirow{2}{*}{$37 \%(31 \%-44 \%)$} & $55 / 80$ & \multirow{2}{*}{$69 \%(61 \%-76 \%)$} & \multirow{2}{*}{$0.54(0.45-0.65)$} \\
\hline Flamm et al ${ }^{12}$ & $55 / 134$ & & $47 / 67$ & & \\
\hline
\end{tabular}

Abbreviation: $\mathrm{Cl}$, confidence interval. 
Table 4 Direct comparison of the proportion of patients achieving a sustained virologic response, relapsing to treatment, or discontinuing treatment in the trial intervention (telaprevir provided at a dose of $750 \mathrm{mg}$ three times per day during weeks $\mathrm{I}-12$ of a 48-week treatment course and coadministered with pegylated interferon alpha plus ribavirin) and the trial control (matched placebo coadministered with pegylated interferon alpha plus ribavirin for 48 weeks)

\begin{tabular}{|c|c|c|c|c|c|}
\hline \multirow[t]{2}{*}{ Trial } & \multicolumn{2}{|c|}{ Intervention } & \multicolumn{2}{|c|}{ Control } & \multirow{2}{*}{$\begin{array}{l}\text { Relative risk } \\
\qquad(95 \% \mathrm{CI})\end{array}$} \\
\hline & $\mathbf{N}$ & $\begin{array}{l}\text { Pooled } \\
(95 \% \mathrm{Cl})\end{array}$ & $\mathbf{N}$ & $\begin{array}{l}\text { Pooled } \\
(95 \% \mathrm{Cl})\end{array}$ & \\
\hline \multicolumn{6}{|c|}{ Sustained virologic response } \\
\hline \multicolumn{6}{|l|}{ Naïve patients } \\
\hline Jacobson et $\mathrm{al}^{8}$ & $271 / 363$ & \multirow{2}{*}{$72 \%(65 \%-79 \%)$} & $|58 / 36|$ & \multirow{2}{*}{$43 \%(39 \%-48 \%)$} & \multirow{2}{*}{$1.69(1.50-1.91)$} \\
\hline McHutchison et $\mathrm{al}^{9}$ & $53 / 79$ & & $31 / 75$ & & \\
\hline \multicolumn{6}{|l|}{ Experienced patients } \\
\hline Zeuzem et al ${ }^{14}$ & $171 / 266$ & $64 \%(60 \%-68 \%)$ & $22 / 132$ & $17 \%(13 \%-22 \%)$ & $3.86(2.92-5.09)$ \\
\hline \multicolumn{6}{|l|}{ Relapse } \\
\hline \multicolumn{6}{|l|}{ Naïve patients } \\
\hline Jacobson et $\mathrm{al}^{8}$ & $27 / 3 \mid 4$ & \multirow{2}{*}{$8 \%(6 \%-11 \%)$} & $64 / 229$ & \multirow{2}{*}{$27 \%(22 \%-33 \%)$} & \multirow{2}{*}{$0.30(0.20-0.45)$} \\
\hline McHutchison et $\mathrm{al}^{9}$ & $3 / 51$ & & $8 / 35$ & & \\
\hline \multicolumn{6}{|l|}{ Experienced patients } \\
\hline Zeuzem et al ${ }^{14}$ & $26 / 204$ & $13 \%(10 \%-16 \%)$ & $33 / 55$ & $60 \%(51 \%-69 \%)$ & $0.21(0.16-0.29)$ \\
\hline \multicolumn{6}{|l|}{ Discontinuation } \\
\hline \multicolumn{6}{|l|}{ Naïve patients } \\
\hline Jacobson et $\mathrm{al}^{8}$ & $80 / 363$ & \multirow{2}{*}{$26 \%(17 \%-36 \%)$} & $|59 / 36|$ & \multirow{2}{*}{$34 \%(15 \%-55 \%)$} & \multirow{2}{*}{$0.81(0.30-2.22)$} \\
\hline McHutchison et $\mathrm{al}^{9}$ & $25 / 79$ & & $17 / 75$ & & \\
\hline \multicolumn{6}{|l|}{ Experienced patients } \\
\hline Zeuzem et $\mathrm{al}^{14}$ & $100 / 266$ & $38 \%(34 \%-42 \%)$ & $82 / 132$ & $62 \%(56 \%-68 \%)$ & $0.6 I(0.52-0.70)$ \\
\hline
\end{tabular}

Abbreviation: $\mathrm{Cl}$, confidence interval.

peginterferon alpha plus ribavirin (control). The results indicate that naïve and experienced patients treated with a standard dose-duration regimen of boceprevir or telaprevir in combination with peginterferon alpha plus ribavirin are generally more likely to achieve a sustained virologic response, less likely to relapse to treatment, and less likely to discontinue treatment when compared to those treated with peginterferon alpha plus ribavirin alone.

Table 5 shows the results of the indirect comparison between standard-dose duration regimens of boceprevir coadministered with peginterferon alpha plus ribavirin and standard-dose duration regimens of telaprevir coadministered with peginterferon alpha plus ribavirin. The results indicate that there are no differences between standard dose-duration regimens of boceprevir and telaprevir in terms of sustained virologic response, relapse to treatment, and discontinuation of treatment. Figures 2 and 3 graphically display results using a forest plot.

\section{Response-guided durations that included boceprevir or telaprevir among all patients}

Two randomized placebo-controlled boceprevir trials (one conducted among treatment-naïve patients and one conducted among treatment-experienced patients) included response-guided therapy arms, ${ }^{5,11}$ and one randomized placebo-controlled telaprevir trial (conducted among treatment-naïve patients) included response-guided therapy arms. ${ }^{8}$

Tables A and B in the Appendix show the results of the direct comparison between response-guided therapy regimens of telaprevir or boceprevir coadministered with peginterferon alpha plus ribavirin (intervention) and placebo coadministered with peginterferon alpha plus ribavirin (control). The results indicate that naive and experienced patients receiving a response-guided therapy regimen consisting of boceprevir or telaprevir in combination with peginterferon alpha plus ribavirin are generally more likely to achieve a sustained virologic response, less likely to relapse to treatment, and less likely to discontinue treatment when compared to those treated with peginterferon alpha plus ribavirin alone.

Table 6 shows the results of the indirect comparison between response-guided therapy regimens of boceprevir coadministered with peginterferon alpha plus ribavirin and response-guided therapy regimens of telaprevir coadministered with peginterferon alpha plus ribavirin. The results indicate that there are no differences between boceprevir and 
Table 5 Adjusted indirect comparison of the proportion of patients achieving a sustained virologic response, relapsing to treatment, or discontinuing treatment in the standard dose-duration interventions boceprevir and telaprevir

\begin{tabular}{|c|c|c|c|c|c|}
\hline & Boceprevir & & Telaprevir & $\begin{array}{c}\text { Relative risk } \\
\qquad(95 \% \mathrm{Cl})\end{array}$ & $P$ value \\
\hline \multicolumn{6}{|c|}{ Sustained virologic response } \\
\hline \multicolumn{6}{|l|}{ Patients } \\
\hline Naïve & $1.91(1.65-2.21)$ & & $1.69(1.50-1.91)$ & $1.14(0.93-1.37)$ & 0.20 \\
\hline Experienced & $3.09(2.24-4.28)$ & & $3.86(2.92-5.09)$ & $0.81(0.52-1.23)$ & 0.30 \\
\hline \multicolumn{6}{|l|}{ Relapse } \\
\hline \multicolumn{6}{|l|}{ Patients } \\
\hline Naïve & $0.24(0.06-1.00)$ & & $0.30(0.20-0.45)$ & $0.80(0.18-3.45)$ & 0.77 \\
\hline Experienced & $0.36(0.20-0.62)$ & & $0.21(0.16-0.29)$ & $1.71(0.90-3.24)$ & 0.10 \\
\hline \multicolumn{6}{|c|}{ Discontinuation } \\
\hline \multicolumn{6}{|l|}{ Patients } \\
\hline Naïve & $0.65(0.47-0.89)$ & & $0.81(0.30-2.22)$ & $0.80(0.28-2.29)$ & 0.72 \\
\hline Experienced & $0.54(0.45-0.65)$ & & $0.61(0.52-0.70)$ & $0.88(0.69-1.12)$ & 0.30 \\
\hline \multicolumn{6}{|c|}{ Abbreviation: $\mathrm{Cl}$, confidence interval. } \\
\hline & ined virologic resp & & & $1.14(0.93,1.37)$ & \\
\hline & $\mathrm{Re}$ & & 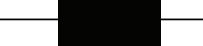 & $0.80(0.18,3.45)$ & \\
\hline \multicolumn{6}{|c|}{$0.80(0.28,2.29)$} \\
\hline & 0.1 & 0.2 & 0.5 & $\sqrt{5}$ & \\
\hline & & $\begin{array}{l}\text { Favors } \\
\text { telaprevir }\end{array}$ & & $\begin{array}{l}\text { vors } \\
\text { ceprevir }\end{array}$ & \\
\hline
\end{tabular}

Figure 2 Forest plot of indirect comparison of standard dose-duration treatments in naive patients addressing sustained virologic response, relapse, and discontinuation.

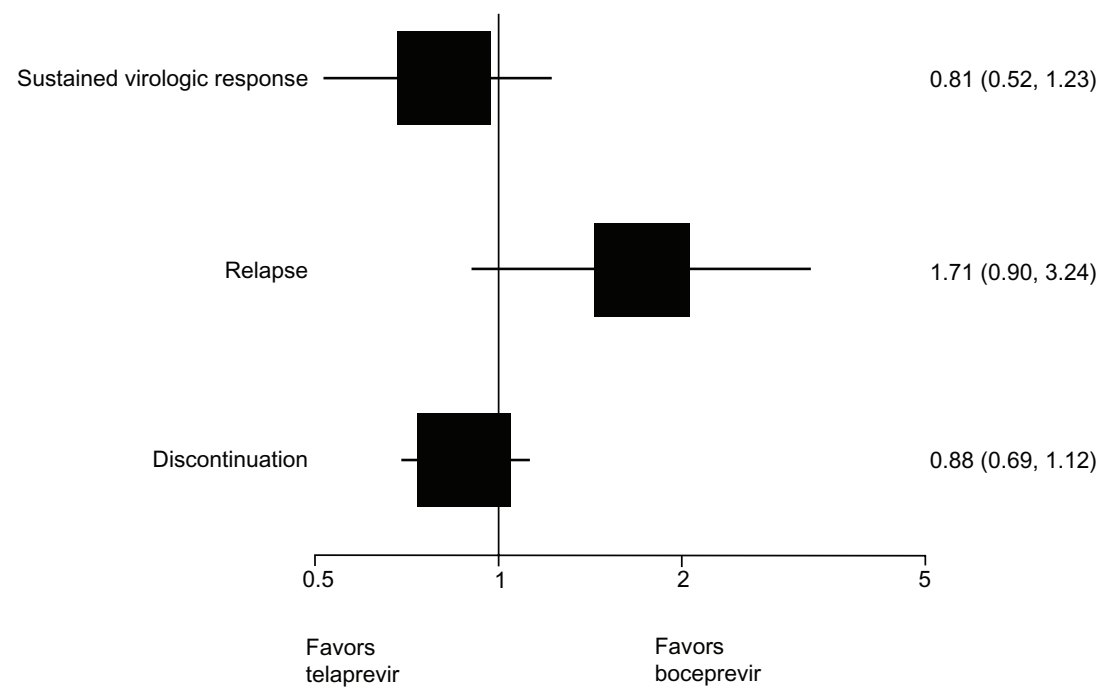

Figure 3 Forest plot of indirect comparison of standard dose-duration treatments in experienced patients addressing sustained virologic response, relapse, and discontinuation. 
Table 6 Adjusted indirect comparison of the proportion of patients achieving a sustained virologic response, relapsing to treatment, or discontinuing treatment in the response-guided therapy interventions boceprevir and telaprevir

\begin{tabular}{|c|c|c|c|c|}
\hline & Boceprevir & Telaprevir & Relative risk $(95 \% \mathrm{CI})$ & $P$ value \\
\hline \multicolumn{5}{|c|}{ Sustained virologic response } \\
\hline \multicolumn{5}{|l|}{ Patients } \\
\hline Naïve & $1.69(1.44-1.96)$ & $1.71(1.50-1.95)$ & $\mathrm{I} .00(0.82-1.23)$ & 0.87 \\
\hline Experienced & $2.76(1.81-4.35)$ & - & - & - \\
\hline \multicolumn{5}{|l|}{ Relapse } \\
\hline \multicolumn{5}{|l|}{ Patients } \\
\hline Naïve & $0.42(0.30-0.59)$ & $0.32(0.24-0.43)$ & I.3I (0.84-2.05) & 0.25 \\
\hline Experienced & $0.48(0.29-0.80)$ & - & - & - \\
\hline \multicolumn{5}{|c|}{ Discontinuation } \\
\hline \multicolumn{5}{|l|}{ Patients } \\
\hline Naïve & $0.67(0.60-0.75)$ & $0.62(0.54-0.72)$ & $1.08(0.90-1.21)$ & 0.60 \\
\hline Experienced & $0.47(0.39-0.56)$ & - & - & - \\
\hline
\end{tabular}

Abbreviation: $\mathrm{Cl}$, confidence interval.

telaprevir in terms of sustained virologic response, relapse to treatment, and discontinuation of treatment for naïve patients treated with a response-guided regimen. No trials included treatment-experienced patients treated with a responseguided therapy regimen of telaprevir; and therefore, a comparison could not be made for this group. Figure 4 graphically displays the results using a forest plot.

\section{Sensitivity analysis}

All dose-durations of boceprevir or telaprevir among all patients

All four randomized placebo-controlled boceprevir trials $^{5,6,11,12}$ and all six randomized placebo-controlled telaprevir trials ${ }^{7-10,13,14}$ contributed to the analysis of all dosedurations combined.
Tables $\mathrm{C}-\mathrm{F}$ in the Appendix show the results of the direct comparison between all dose-durations of telaprevir or boceprevir coadministered with peginterferon alpha plus ribavirin (intervention) and placebo coadministered with peginterferon alpha plus ribavirin (control). The results indicate that, in general, naïve and experienced patients treated with boceprevir or telaprevir in combination with peginterferon alpha plus ribavirin are more likely to achieve a sustained virologic response, less likely to relapse to treatment, and less likely to discontinue treatment when compared to those treated with peginterferon alpha plus ribavirin alone.

Indirect comparisons suggest that experienced patients treated with boceprevir at any point in a 48-week treatment course are more likely to relapse compared to experienced

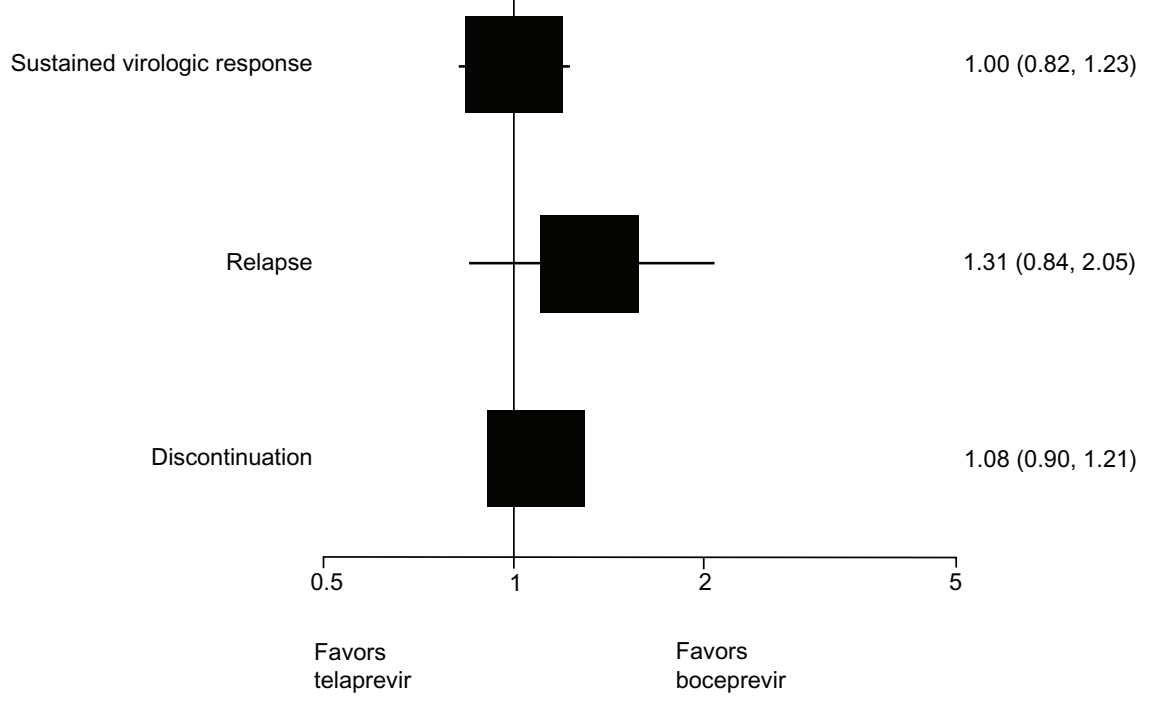

Figure 4 Forest plot of indirect comparison of response-guided therapy treatments in naïve patients addressing sustained virologic response, relapse, and discontinuation. 
patients treated with telaprevir (Table G, Appendix). However, closer inspection of the results reveals that this finding is driven by a large absolute difference in relapse among the control arms rather than the treatment arms (Tables $\mathrm{C}$ and $D$, Appendix). No other differences were observed between boceprevir and telaprevir for all dose-durations (Tables $\mathrm{G}$ and H, Appendix).

\section{Multiple treatment comparison}

The multiple treatment comparison of the primary outcome for naïve patients showed an almost identical result to the frequentist method $(1.34,95 \%$ creditable interval 0.46-4.03). Given the sparseness of the network, it was not possible to apply a Bayesian approach to the experienced patients.

\section{Meta-regression}

For sustained virologic response, the meta-regression analysis of the indirect evidence demonstrated that the magnitude of effect significantly depends on whether patients are treatment-naïve or treatment-experienced (RR 1.96, 95\% CI 1.60-2.42), but not the type of peginterferon alpha used (RR 1.12, 95\% CI 0.84-1.55). Controlling for both variables, no significant difference was detected for boceprevir versus telaprevir (RR 1.12, 95\% CI 0.82-1.52). For relapse, no significant difference was detected for treatment-naïve or treatment-experienced patients (RR 0.88, 95\% CI 0.31-2.47) or type of peginterferon alpha (RR $0.79,95 \%$ CI $0.17-3.70$ ). Controlling for both variables, no significant difference was detected for boceprevir versus telaprevir (RR 0.80, 95\% CI 0.17-3.75). For discontinuation, no significant difference was detected for treatment-naïve or treatment-experienced patients (RR $0.76,95 \%$ CI $0.36-1.61$ ) or type of peginterferon alpha (RR 0.82, 95\% CI 0.27-2.51). Controlling for both variables, no significant difference was detected for boceprevir versus telaprevir (RR 1.07, 95\% CI 0.35-3.27). Sensitivity meta-regression analyses using only one covariate in the model yielded similar results to the model including both covariates.

\section{Subgroups}

Standard dose-durations of boceprevir or telaprevir among patients with compensated cirrhosis

All four randomized placebo-controlled boceprevir trials (two conducted among treatment-naïve patients and two conducted among treatment-experienced patients $)^{5,6,11,12}$ and two randomized placebo-controlled telaprevir trials (one conducted among treatment-naïve patients and one conducted among treatment-experienced patients $)^{8,14}$ included data on sustained virologic response among compensated cirrhosis patients treated with standard doseduration. Relapse and discontinuation data was not available for compensated cirrhosis patients treated with standard dose-durations.

Tables $\mathrm{I}$ and $\mathrm{J}$ in the Appendix show the results of the direct comparison between standard dose-duration regimens of telaprevir or boceprevir coadministered with peginterferon alpha plus ribavirin (intervention) and placebo coadministered with peginterferon alpha plus ribavirin (control) for patients with compensated cirrhosis. The results indicate that, in general, those treated with standard dose-duration boceprevir or telaprevir in combination with peginterferon alpha plus ribavirin are generally more likely to achieve a sustained virologic response when compared to those treated with peginterferon alpha plus ribavirin alone.

Table $\mathrm{K}$ in the Appendix shows the results of the indirect comparison between standard dose-duration regimens of boceprevir coadministered with peginterferon alpha plus ribavirin and standard dose-duration regimens of telaprevir coadministered with peginterferon alpha plus ribavirin for patients with compensated cirrhosis. The results show that there are no differences between standard dose-duration regimens of boceprevir and telaprevir among patients with compensated cirrhosis.

\section{Response-guided therapy durations that included boceprevir or telaprevir among patients \\ with compensated cirrhosis}

Two randomized placebo-controlled boceprevir trials (one conducted among treatment-naïve patients and one conducted among treatment-experienced patients) $)^{5,11}$ and one randomized placebo-controlled telaprevir trial (conducted among treatment-naïve patients) ${ }^{8}$ included data on sustained virologic response among compensated cirrhosis patients treated with a response-guided therapy duration. Relapse and discontinuation data were not available for compensated cirrhosis patients treated with a response-guided therapy duration.

Tables $\mathrm{L}$ and $\mathrm{M}$ in the Appendix show the results of the direct comparison between response-guided therapy regimens of telaprevir or boceprevir coadministered with peginterferon alpha plus ribavirin (intervention) and placebo coadministered with peginterferon alpha plus ribavirin (control) for patients with compensated cirrhosis. The results indicate that treatment-experienced patients with 
compensated cirrhosis provided with a response-guided therapy regimen that included boceprevir in combination with peginterferon alpha plus ribavirin are more likely to achieve a sustained virologic response when compared to those treated with peginterferon alpha plus ribavirin alone. No telaprevir trial included data on treatment-experienced compensated cirrhosis patients provided with a responseguided therapy regimen. No difference was observed between treatment-naïve compensated cirrhosis patients provided with a response-guided therapy regimen that included boceprevir or telaprevir in combination with peginterferon alpha plus ribavirin when compared to similar patients provided with peginterferon alpha plus ribavirin alone.

Table $\mathrm{N}$ in the Appendix shows the results of the indirect comparison between response-guided therapy regimens of boceprevir coadministered with peginterferon alpha plus ribavirin and response-guided therapy regimens of telaprevir coadministered with peginterferon alpha plus ribavirin for patients with compensated cirrhosis. The results indicate that there are no differences between response-guided therapy regimens including boceprevir and telaprevir among treatment-naïve patients with compensated cirrhosis.

\section{Standard dose-durations of boceprevir or telaprevir among prior nonresponding and prior relapsing treatment-experienced patients}

Both randomized placebo-controlled boceprevir trials conducted among experienced patients ${ }^{11,12}$ and one randomized placebo-controlled telaprevir trial conducted among experienced patients ${ }^{14}$ included sustained virologic response data stratified by prior nonresponding and prior relapsing patients for the standard-dose duration arms. Relapse and discontinuation data were not available for prior nonresponding and prior relapsing patients.

Tables $\mathrm{O}$ and $\mathrm{P}$ in the Appendix show the results of the direct comparison between standard-dose duration regimens of telaprevir or boceprevir coadministered with peginterferon alpha plus ribavirin (intervention) and placebo coadministered with peginterferon alpha plus ribavirin (control) for prior nonresponding and prior relapsing patients. The results indicate that, in general, both prior nonresponding and relapsing patients treated with a standard-dose duration regimen of boceprevir or telaprevir in combination with peginterferon alpha plus ribavirin are more likely to achieve a sustained virologic response when compared to those treated with peginterferon alpha plus ribavirin alone.

Table Q in the Appendix shows the results of the indirect comparison between standard-dose duration regimens of boceprevir coadministered with peginterferon alpha plus ribavirin and standard-dose duration regimens of telaprevir coadministered with peginterferon alpha plus ribavirin for prior nonresponding and prior relapsing patients. The results show that there are no differences in terms of sustained virologic response between boceprevir and telaprevir for prior nonresponding and prior relapsing patients.

\section{Response-guided therapy durations that included} boceprevir or telaprevir among prior nonresponding and prior relapsing treatment-experienced patients

One randomized placebo-controlled boceprevir trial conducted among experienced patients ${ }^{11}$ included sustained virologic response data stratified for prior relapsing patients for a response-guided therapy arm. Data on prior nonresponders was not available in this trial arm, nor was data on relapses and discontinuations. No telaprevir trial evaluated treatment-experienced patients treated with a responseguided therapy regimen.

Table $\mathrm{R}$ in the Appendix shows the results of the direct comparison between response-guided therapy regimens of boceprevir coadministered with peginterferon alpha plus ribavirin (intervention) and placebo coadministered with peginterferon alpha plus ribavirin (control) for prior relapsing patients. The results indicate that prior relapsing patients treated with boceprevir in combination with peginterferon alpha plus ribavirin are generally more likely to achieve a sustained virologic response when compared to those treated with peginterferon alpha plus ribavirin alone.

\section{Adverse events}

\section{Adverse events among all patients treated with} standard dose-duration boceprevir or telaprevir

All four randomized placebo-controlled boceprevir trials (two conducted among treatment-naïve patients and two conducted among treatment-experienced patients) that included standard-dose duration $\operatorname{arms}^{5,6,11,12}$ and three randomized placebo-controlled telaprevir trials (two conducted among treatment-naive patients and one conducted among treatmentexperienced patients) that included standard dose-duration $\operatorname{arms}^{8,9,14}$ provided adverse event data. Tables $\mathrm{S}$ and $\mathrm{T}$ in the Appendix show the results of the direct comparison between standard dose-duration regimens of telaprevir or boceprevir coadministered with peginterferon alpha plus ribavirin (intervention) and placebo coadministered with peginterferon alpha plus ribavirin (control).

Table 7 shows the results of the indirect comparison between standard-dose duration regimens of boceprevir 
Table 7 Adjusted indirect comparison of adverse events between boceprevir and telaprevir standard dose-duration therapy interventions

\begin{tabular}{|c|c|c|c|c|}
\hline & Boceprevir & Telaprevir & Relative risk $(95 \% \mathrm{CI})$ & $P$ value \\
\hline \multicolumn{5}{|l|}{ Anemia } \\
\hline \multicolumn{5}{|l|}{ Patients } \\
\hline Naïve & $1.63(1.39-1.92)$ & $1.51(0.88-2.61)$ & $1.08(0.61-1.90)$ & 0.79 \\
\hline Experienced & $1.30(0.42-4.03)$ & $1.96(1.43-2.68)$ & $0.66(0.21-2.14)$ & 0.49 \\
\hline \multicolumn{5}{|l|}{ Neutropenia } \\
\hline \multicolumn{5}{|l|}{ Patients } \\
\hline Naïve & $1.51(0.85-2.68)$ & $0.81(0.54-1.04)$ & $1.86(0.96-3.6 \mathrm{I})$ & 0.06 \\
\hline Experienced & $0.86(0.60-1.23)$ & $1.35(0.90-2.02)$ & $0.64(0.37-1.09)$ & 0.10 \\
\hline \multicolumn{5}{|l|}{ Rash } \\
\hline \multicolumn{5}{|l|}{ Patients } \\
\hline Naïve & $1.05(0.87-1.27)$ & $1.49(1.24-1.80)$ & $0.70(0.54-0.92)$ & 0.01 \\
\hline Experienced & $1.99(1.06-3.72)$ & $1.97(1.50-2.58)$ & $1.01(0.51-2.00)$ & 0.98 \\
\hline \multicolumn{5}{|l|}{ Pruritus } \\
\hline \multicolumn{5}{|l|}{ Patients } \\
\hline Naïve & $0.95(0.80-1.13)$ & I.4I (I.20-I.66) & $0.67(0.53-0.85)$ & 0.001 \\
\hline Experienced & $1.10(0.73-1.65)$ & $1.90(1.54-2.35)$ & $0.58(0.37-0.92)$ & 0.02 \\
\hline
\end{tabular}

Abbreviations: $\mathrm{Cl}$, confidence interval.

coadministered with peginterferon alpha plus ribavirin and standard-dose duration regimens of telaprevir coadministered with peginterferon alpha plus ribavirin. The results indicate that naïve patients treated with a standard-dose duration regimen of telaprevir in combination with peginterferon alpha plus ribavirin are more likely to develop a rash when compared to those treated with a standard-dose duration regimen of boceprevir in combination with peginterferon alpha plus ribavirin. Furthermore, both naïve and experienced patients treated with a standard dose-duration regimen of telaprevir in combination with peginterferon alpha plus ribavirin are more likely to develop pruritus when compared to those treated with a standard dose-duration regimen of boceprevir in combination with peginterferon alpha plus ribavirin. No differences between boceprevir and telaprevir were observed for anemia and neutropenia.

\section{Adverse events among all patients treated} with response-guided therapy durations that included boceprevir or telaprevir

Two randomized placebo-controlled boceprevir trials (one conducted among treatment-naïve patients and one conducted among treatment-experienced patients) that included response-guided therapy $\operatorname{arms}^{5,11}$ and one randomized placebo-controlled telaprevir trial (conducted among treatment-naïve patients) that included a response guided therapy $\mathrm{arm}^{8}$ provided adverse event data.

Tables $\mathrm{U}$ and $\mathrm{V}$ in the Appendix show the results of the direct comparison between response-guided therapy regimens of boceprevir or telaprevir coadministered with peginterferon alpha plus ribavirin (intervention) and placebo coadministered with peginterferon alpha plus ribavirin (control).

Table 8 shows the results of the indirect comparison between response-guided therapy regimens of boceprevir coadministered with peginterferon alpha plus ribavirin and response-guided therapy regimens of telaprevir coadministered with peginterferon alpha plus ribavirin. The results indicate that naïve patients treated with a response-guided therapy regimen that included boceprevir in combination with peginterferon alpha plus ribavirin are more likely to develop neutropenia when compared to those treated with a response-guided therapy regimen that included telaprevir in combination with peginterferon alpha plus ribavirin. Furthermore, naïve patients treated with a response-guided therapy regimen that included telaprevir in combination with peginterferon alpha plus ribavirin are more likely to develop rash or pruritus when compared to those treated with a response-guided therapy regimen that included boceprevir in combination with peginterferon alpha plus ribavirin. No differences were observed between boceprevir and telaprevir for anemia.

\section{Discussion}

The results of the direct analysis indicate that patients provided a standard-dose duration or response-guided therapy duration of boceprevir or telaprevir in combination with peginterferon alpha plus ribavirin are generally more likely to achieve a sustained virologic response, less likely to 
Table 8 Adjusted indirect comparison of adverse events between boceprevir and telaprevir response-guided therapy duration interventions

\begin{tabular}{|c|c|c|c|c|}
\hline & Boceprevir & Telaprevir & Relative risk $(95 \% \mathrm{CI})$ & $P$ value \\
\hline \multicolumn{5}{|l|}{ Anemia } \\
\hline \multicolumn{5}{|l|}{ Patients } \\
\hline Naïve & $1.68(1.47-1.92)$ & $1.96(1.64-2.33)$ & $0.86(0.69-1.07)$ & 0.17 \\
\hline Experienced & $2.16(1.55-3.02)$ & - & - & - \\
\hline \multicolumn{5}{|l|}{ Neutropenia } \\
\hline \multicolumn{5}{|l|}{ Patients } \\
\hline Naïve & I. 18 (0.98-I.42) & $0.81(0.65-1.02)$ & $1.46(1.09-1.95)$ & 0.05 \\
\hline \multicolumn{5}{|l|}{ Rash } \\
\hline \multicolumn{5}{|l|}{ Patients } \\
\hline Naïve & I.II (0.92-I.33) & $1.48(1.26-1.74)$ & $0.75(0.59-0.96)$ & 0.02 \\
\hline Experienced & $3.33(1.63-6.83)$ & - & - & - \\
\hline \multicolumn{5}{|l|}{ Pruritus } \\
\hline \multicolumn{5}{|l|}{ Patients } \\
\hline Naïve & $0.88(0.73-1.04)$ & I.3I (I.16-I.48) & $0.67(0.54-0.83)$ & 0.0003 \\
\hline Experienced & I.06 (0.70-1.59) & - & - & - \\
\hline
\end{tabular}

Abbreviation: $\mathrm{Cl}$, confidence interval.

relapse to treatment, and less likely to discontinue treatment when compared with those treated with peginterferon plus ribavirin alone. The results of the indirect analysis indicate that there are no significant differences between boceprevir and telaprevir in terms of sustained virologic response, relapse, or discontinuation of therapy for patients treated with standard-dose duration or response-guided therapy duration. These findings were consistent in both treatmentnaïve and treatment-experienced study populations.

There are several issues to consider when interpreting the analysis. The authors are confident that all key studies were identified in the exhaustive search, and believe it unlikely that publication bias would exist in this high profile field. Good interobserver agreement was found between the included studies. The analysis used direct comparisons of telaprevir or boceprevir in combination with peginterferon alpha and ribavirin, as well as indirect comparisons of telaprevir and boceprevir in combination with peginterferon alpha and ribavirin. The validity of indirect comparisons has received extensive research. ${ }^{37-43}$ However, it should be recognized that the strength of inference from indirect comparisons is limited by the inherent differences of the included studies. ${ }^{19}$ Some differences in the populations and methodology were found and addressed using metaregression and subgroup analyses, as discussed further below. Additionally, where possible, the $\mathrm{I}^{2}$ statistic was obtained and showed that in most cases there was little variation between studies, although heterogeneity tests are poorly powered, further supporting the use of indirect comparisons.
In the absence of direct evidence, the indirect comparison method is widely accepted by agencies such as the United Kingdom National Institute for Health and Clinical Excellence, the Canadian Drug Safety and Effectiveness Network, and the United States Agency for Healthcare Research and Quality. The largest evaluation of the consistency between direct and indirect comparisons of trials, published in 2011, found that there was a statistically significant inconsistency in only $14 \%$ of evaluations. ${ }^{40}$ However, indirect comparisons may be underpowered to determine treatment differences, particularly when there is severe imbalance between the number of trials available for one treatment versus the other. ${ }^{44}$ The present study examined whether differences between treatments were significantly different in terms of a priori determined outcomes. The study did not determine whether the treatments were noninferior because noninferiority assumes that there is a reference drug. ${ }^{45}$ If the noninferiority margins were set as an upper CI of 0.8 and lower CI of 0.5 for sustained virologic response, then treatments appear to be noninferior.

There are certain trial level characteristics to consider. Telaprevir trials used a backbone therapy of predominantly peg-2a, while boceprevir trials used predominantly peg$2 \mathrm{~b}$. Some studies have shown that peg- 2 a plus ribavirin is favorable over peg-2b plus ribavirin in terms of sustained virologic response. ${ }^{46,21}$ However, based on the results of the meta-regressions, this effect is minimal and should not have greatly influenced the outcomes in the present study. The weight-based ribavirin dosing strategy also differed between 
peg-2a and peg-2b; however, the level of detail necessary to control for this variable in the analysis was not available in the published literature.

The analysis of patients with compensated cirrhosis indicates that triple therapy including boceprevir or telaprevir is generally advantageous to conventional peginterferon alpha and ribavirin therapy in terms of sustained virologic response. However, the number of patients with compensated cirrhosis in the included studies was small, and the data reported on this subgroup were limited. Therefore, drawing concrete conclusions regarding this treatment subgroup should be cautioned.

The analysis utilized the available data for treatmentexperienced patients, as presented in the trial publications, to examine sustained virologic response, relapse, and treatment discontinuation. A priori, it was known that most trials also presented separate data for prior relapsing and prior nonresponding treatment-experienced patients; and therefore, it was also possible to conduct analyses for these subgroups. However, there is a major limitation to this approach. The term nonresponder is typically used to refer to the combination of partial responders and null responders. However, the boceprevir trials, conducted among treatment-experienced patients, did not recruit null responders. In this regard, the treatment populations are dissimilar between the boceprevir and telaprevir trials, and the results of the analysis may underestimate the efficacy of telaprevir and/or overestimate the efficacy of boceprevir in the prior nonresponse subgroup of patients. In spite of this, in nontrial clinical practice, the history of prior on-treatment virologic response to treatment is often incomplete or missing altogether. Therefore, composite estimates for treatmentexperienced patients, as provided by the present analysis, may be of clinical utility.

The analysis of adverse events indicated that skin conditions, such as rash and pruritus were more common in those treated with boceprevir or telaprevir in combination with peginterferon alpha plus ribavirin than peginterferon alpha plus ribavirin alone. The indirect analysis indicates that these conditions were more likely to occur with those taking telaprevir than boceprevir. The primary concern related to the dermatological complications of telaprevir is that of severe rash, and in rare cases, Stevens-Johnson syndrome. ${ }^{47}$

Cytopenias are a well-recognized side effect of peginterferon alpha and ribavirin therapy. The analysis showed that both boceprevir and telaprevir generally appear to exacerbate such conditions. Indirect analyses comparing boceprevir and telaprevir found that neutropenia is more likely to occur in boceprevir recipients provided with a response-guided therapy regimen. However, there is little, if any, clinical consequence with treatment-induced neutropenia in terms of infectious diseases complication risk. ${ }^{48}$

In conclusion, no significant differences were found between the two direct-acting agents in terms of major clinical endpoints. Adverse event profiles differ between agents and are key variables that clinicians and patients will consider when selecting a protease inhibitor. Recognizing that indirect estimates are best estimates in the absence of direct (headto-head) evaluations, the authors believe that the present study has implications for clinicians in terms of choosing the most effective and most tolerable direct-acting agent.

\section{Disclosure}

The authors report no conflicts of interest in this work.

\section{References}

1. Ciesek S, Manns MP. Hepatitis in 2010: the dawn of a new era in HCV therapy. Nat Rev Gastroenterol Hepatol. 2011;8(2):69-71.

2. Hofmann WP, Zeuzem S. A new standard of care for the treatment of chronic HCV infection. Nat Rev Gastroenterol Hepatol. 2011;8(5): 257-264.

3. Poordad F, Khungar V. Emerging therapeutic options in hepatitis $C$ virus infection. Am J Manag Care. 2011;17 Suppl 4:S123-S130.

4. Asselah T, Marcellin P. New direct-acting antivirals' combination for the treatment of chronic hepatitis C. Liver Int. 2011;31 Suppl 1: 68-77.

5. Poordad F, McCone J Jr, Bacon BR, et al. Boceprevir for untreated chronic HCV genotype 1 infection. N Engl J Med. 2011;364(13):1195-1206.

6. Kwo PY, Lawitz EJ, McCone J, et al. Efficacy of boceprevir, an NS3 protease inhibitor, in combination with peginterferon alfa- $2 \mathrm{~b}$ and ribavirin in treatment-naive patients with genotype 1 hepatitis $\mathrm{C}$ infection (SPRINT-1): an open-label, randomised, multicentre phase 2 trial. Lancet. 2010;376(9742):705-716.

7. Hezode C, Forestier N, Dusheiko G, et al. Telaprevir and peginterferon with or without ribavirin for chronic $\mathrm{HCV}$ infection. $N$ Engl $J$ Med. 2009;360(18):1839-1850.

8. Jacobson IM, McHutchison JG, Dusheiko G, et al. Telaprevir for previously untreated chronic hepatitis C virus infection. N Engl J Med. 2011;364(25):2405-2416.

9. McHutchison JG, Everson GT, Gordon SC, et al. Telaprevir with peginterferon and ribavirin for chronic HCV genotype 1 infection. N Engl J Med. 2009;360(18):1827-1838.

10. Kumada H, Toyota J, Okanoue T, Chayama K, Tsubouchi H, Hayashi N. Telaprevir with peginterferon and ribavirin for treatment-naive patients chronically infected with HCV of genotype 1 in Japan. J Hepatol. 2012; 56(1):78-84.

11. Bacon BR, Gordon SC, Lawitz E, et al. Boceprevir for previously treated chronic HCV genotype 1 infection. NEngl J Med. 2011;364(13): $1207-1217$.

12. Flamm S, Lawitz E, Jacobson I, et al. High sustained virological response (SVR) among genotype 1 previous non-responders and relapsers to peginterferon/ribavirin when re-treated with boceprevir (BOC) plus peginterferon alfa-2a/ribavirin. J Hepatol. 2011;54:S535-S546. 
13. McHutchison JG, Manns MP, Muir AJ, et al. Telaprevir for previously treated chronic HCV infection. N Engl J Med. 2010;362(14):1292-1303.

14. Zeuzem S, Andreone P, Pol S, et al. Telaprevir for retreatment of $\mathrm{HCV}$ infection. N Engl J Med. 2011;364(25):2417-2428.

15. Meade MO, Cook RJ, Guyatt GH, et al. Interobserver variation in interpreting chest radiographs for the diagnosis of acute respiratory distress syndrome. Am J Respir Crit Care Med. 2000;161(1): 85-90.

16. DerSimonian R, Laird N. Meta-analysis in clinical trials. Control Clin Trials. 1986;7(3):177-188.

17. Fleiss JL. The statistical basis of meta-analysis. Stat Methods Med Res. 1993;2(2):121-145.

18. Higgins JP, Thompson SG. Quantifying heterogeneity in a metaanalysis. Stat Med. 2002;21(11):1539-1558.

19. Bucher HC, Guyatt GH, Griffith LE, Walter SD. The results of direct and indirect treatment comparisons in meta-analysis of randomized controlled trials. J Clin Epidemiol. 1997;50(6):683-691.

20. Lu G, Ades AE. Combination of direct and indirect evidence in mixed treatment comparisons. Stat Med. 2004;23(20):3105-3124.

21. Awad T, Thorlund K, Hauser G, Stimac D, Mabrouk M, Gluud C. Peginterferon alpha-2a is associated with higher sustained virological response than peginterferon alfa-2b in chronic hepatitis $\mathrm{C}$ : systematic review of randomized trials. Hepatology. 2010;51(4):1176-1184.

22. Ihaka R, Gentleman R. The R project for statistical computing [computer software]. Auckland: University of Auckland; 1993

23. Adiwijaya B, Hare B, Caron PR, et al. Rapid decrease of wild-type hepatitis C virus on telaprevir treatment. Antivir Ther. 2009;14(4):591-595.

24. Forestier N, Reesink HW, Weegink CJ, et al. Antiviral activity of telaprevir (VX-950) and peginterferon alfa-2a in patients with hepatitis C. Hepatology. 2007;46(3):640-648.

25. Garg V, van Heeswijk R, Lee JE, Alves K, Nadkarni P, Luo X. Effect of telaprevir on the pharmacokinetics of cyclosporine and tacrolimus. Hepatology. 2011;54(1):20-27.

26. Gelderblom HC, Zeuzem S, Weegink CJ, et al. Inflammatory markers neopterin and alanine aminotransferase in $\mathrm{HCV}$ patients treated with HCV NS3.4 A protease inhibitor telaprevir (VX-950) and/or peginterferon alfa-2a. Scand J Gastroenterol. 2008;43(9):1122-1127.

27. Guedj J, Perelson A. Second-phase hepatitis C virus RNA decline during telaprevir-based therapy increases with drug effectiveness: implications for treatment duration. Hepatology. 2011;53(6):1801-1808.

28. Kieffer TL, Sarrazin C, Miller JS, et al. Telaprevir and pegylated interferon-alpha-2a inhibit wild-type and resistant genotype 1 hepatitis C virus replication in patients. Hepatology. 2007;46(3): 631-639

29. Lawitz E, Rodriguez-Torres M, Muir AJ, et al. Antiviral effects and safety of telaprevir, peginterferon alfa-2a, and ribavirin for 28 days in hepatitis C patients. J Hepatol. 2008;49(2):163-169.

30. Reesink HW, Zeuzem S, Weegink CJ, et al. Rapid decline of viral RNA in hepatitis C patients treated with VX-950: a phase $\mathrm{Ib}$, placebo-controlled, randomized study. Gastroenterology. 2006;131(4):997-1002.

31. Sarrazin C, Kieffer TL, Bartels D, et al. Dynamic hepatitis C virus genotypic and phenotypic changes in patients treated with the protease inhibitor telaprevir. Gastroenterology. 2007;132(5):1767-1777.
32. Curry S, Qiu P, Tong X. Analysis of HCV resistance mutations during combination therapy with protease inhibitor boceprevir and PEG-IFN alpha-2b using TaqMan mismatch amplification mutation assay. JVirol Methods. 2008;153(2):156-162.

33. Sarrazin C, Rouzier R, Wagner F, et al. SCH 503034, a novel hepatitis $\mathrm{C}$ virus protease inhibitor, plus pegylated interferon alpha2b for genotype 1 nonresponders. Gastroenterology. 2007;132(4): 1270-1278.

34. Susser S, Welsch C, Wang Y, et al. Characterization of resistance to the protease inhibitor boceprevir in hepatitis $\mathrm{C}$ virus-infected patients. Hepatology. 2009;50(6):1709-1718.

35. Marcellin P, Forns X, Goeser T, et al. Telaprevir is effective given every 8 or 12 hours with ribavirin and peginterferon alfa- $2 \mathrm{a}$ or $-2 \mathrm{~b}$ to patients with chronic hepatitis C. Gastroenterology. 2011;140(2):459-468.

36. Sherman KE, Flamm SL, Afdhal NH, et al. Response-guided telaprevir combination treatment for hepatitis C virus infection. $N$ Engl J Med. 2011;365(11):1014-1024.

37. Glenny AM, Altman DG, Song F, et al. Indirect comparisons of competing interventions. Health Technol Assess. 2005;9(26):1-134, iii-iv.

38. Song F, Harvey I, Lilford R. Adjusted indirect comparison may be less biased than direct comparison for evaluating new pharmaceutical interventions. J Clin Epidemiol. 2008;61(5):455-463.

39. Song F, Loke YK, Walsh T, Glenny AM, Eastwood AJ, Altman DG. Methodological problems in the use of indirect comparisons for evaluating healthcare interventions: survey of published systematic reviews. BMJ. 2009;338:b1147.

40. Song F, Xiong T, Parekh-Bhurke S, et al. Inconsistency between direct and indirect comparisons of competing interventions: meta-epidemiological study. BMJ. 2011;343:d4909.

41. Deeks JJ, Dinnes J, D'Amico R, et al. Evaluating non-randomised intervention studies. Health Technol Assess. 2003;7(27):iii-x, 1-173.

42. Song F, Altman DG, Glenny AM, Deeks JJ. Validity of indirect comparison for estimating efficacy of competing interventions: empirical evidence from published meta-analyses. BMJ. 2003;326(7387):472.

43. Song F, Glenny AM, Altman DG. Indirect comparison in evaluating relative efficacy illustrated by antimicrobial prophylaxis in colorectal surgery. Control Clin Trials. 2000;21(5):488-497.

44. Mills EJ, Ghement I, O'Regan C, Thorlund K. Estimating the power of indirect comparisons: a simulation study. PLoS One. 2011;6(1): e16237.

45. Piaggio G, Elbourne DR, Altman DG, Pocock SJ, Evans SJ; CONSORT Group. Reporting of noninferiority and equivalence randomized trials: an extension of the CONSORT statement. JAMA. 2006;295(10):1152-1160.

46. Alavian SM, Behnava B, Tabatabaei SV. The comparative efficacy and safety of peginterferon alpha-2a vs $2 b$ for the treatment of chronic HCV infection: a meta-analysis. Hepat Mon. 2010;10(2):121-131.

47. Cacoub P, Bourlière M, Lübbe J, et al. Dermatological side effects of hepatitis $\mathrm{C}$ and its treatment: patient management in the era of directacting antivirals. J Hepatol. 2012;56(2):455-463.

48. Cooper CL, Al-Bedwawi S, Lee C, Garber G. Rate of infectious complications during interferon-based therapy for hepatitis $\mathrm{C}$ is not related to neutropenia. Clin Infect Dis. 2006;42(12):1674-1678. 


\section{Appendix}

Table A Direct comparison of the proportion of patients achieving a sustained virologic response, relapsing to treatment, or discontinuing treatment in the trial intervention (response-guided therapy duration boceprevir) and the trial control (matched placebo coadministered with pegylated interferon alpha plus ribavirin)

\begin{tabular}{|c|c|c|c|c|c|}
\hline \multirow[t]{2}{*}{ Trial } & \multicolumn{2}{|c|}{ Intervention } & \multicolumn{2}{|c|}{ Control } & \multirow{2}{*}{$\begin{array}{c}\text { Relative risk } \\
(95 \% \mathrm{CI})\end{array}$} \\
\hline & $\mathbf{N}$ & $\begin{array}{l}\text { Pooled } \\
(95 \% \mathrm{CI})\end{array}$ & $\mathbf{N}$ & $\begin{array}{l}\text { Pooled } \\
(95 \% \mathrm{Cl})\end{array}$ & \\
\hline \multicolumn{6}{|c|}{ Sustained virologic response } \\
\hline \multicolumn{6}{|l|}{ Naïve patients } \\
\hline Poordad et $\mathrm{al}^{5}$ & $233 / 368$ & $63 \%(60 \%-67 \%)$ & $137 / 363$ & $38 \%(34 \%-41 \%)$ & $1.69(1.44-1.96)$ \\
\hline \multicolumn{6}{|c|}{ Experienced patients } \\
\hline Bacon et al" & $95 / 162$ & $59 \%(53 \%-64 \%)$ & $17 / 80$ & $22 \%(16 \%-28 \%)$ & $2.76(1.81-4.35)$ \\
\hline \multicolumn{6}{|l|}{ Relapse } \\
\hline \multicolumn{6}{|l|}{ Naïve patients } \\
\hline Poordad et $\mathrm{al}^{5}$ & $24 / 257$ & $9 \%(7 \%-12 \%)$ & $39 / 176$ & $22 \%(\mid 8 \%-27 \%)$ & $0.42(0.30-0.59)$ \\
\hline \multicolumn{6}{|c|}{ Experienced patients } \\
\hline Bacon et al" & $|7 / 1| \mid$ & $16 \%(11 \%-21 \%)$ & $8 / 25$ & $33 \%(21 \%-46 \%)$ & $0.48(0.29-0.80)$ \\
\hline \multicolumn{6}{|l|}{ Discontinuation } \\
\hline \multicolumn{6}{|l|}{ Naïve patients } \\
\hline Poordad et $\mathrm{al}^{5}$ & $139 / 368$ & $38 \%(34 \%-41 \%)$ & $204 / 363$ & $56 \%(53 \%-60 \%)$ & $0.67(0.60-0.75)$ \\
\hline \multicolumn{6}{|c|}{ Experienced patients } \\
\hline Bacon et al" & $52 / 162$ & $32 \%(27 \%-37 \%)$ & $55 / 80$ & $69 \%(61 \%-75 \%)$ & $0.47(0.39-0.56)$ \\
\hline
\end{tabular}

Abbreviation: $\mathrm{Cl}$, confidence interval.

Table B Direct comparison of the proportion of patients achieving a sustained virologic response, relapsing to treatment, or discontinuing treatment in the trial intervention (response-guided therapy duration telaprevir) and the trial control (matched placebo coadministered with pegylated interferon alpha plus ribavirin)

\begin{tabular}{|c|c|c|c|c|c|}
\hline \multirow[t]{2}{*}{$\begin{array}{l}\text { Trial } \\
\end{array}$} & \multicolumn{2}{|c|}{ Intervention } & \multicolumn{2}{|c|}{ Control } & \multirow{2}{*}{$\begin{array}{c}\text { Relative risk } \\
(95 \% \mathrm{CI})\end{array}$} \\
\hline & $\mathbf{N}$ & $\begin{array}{l}\text { Pooled } \\
(95 \% \mathrm{Cl})\end{array}$ & $\mathbf{N}$ & $\begin{array}{l}\text { Pooled } \\
(95 \% \mathrm{Cl})\end{array}$ & \\
\hline \multicolumn{6}{|c|}{ Sustained virologic response } \\
\hline \multicolumn{6}{|l|}{ Naïve patients } \\
\hline Jacobson et $\mathrm{al}^{8}$ & $\begin{array}{l}27 I / 363 \\
250 / 364\end{array}$ & $72 \%(66 \%-77 \%)$ & $|58 / 36|$ & $44 \%(40 \%-47 \%)$ & I.7I (1.50-I.95) \\
\hline \multicolumn{6}{|l|}{ Relapse } \\
\hline \multicolumn{6}{|l|}{ Naïve patients } \\
\hline Jacobson et al ${ }^{8}$ & $\begin{array}{l}27 / 3 \mid 4 \\
28 / 295\end{array}$ & $9 \%(7 \%-12 \%)$ & $64 / 229$ & $28 \%(24 \%-32 \%)$ & $0.32(0.24-0.43)$ \\
\hline \multicolumn{6}{|l|}{ Discontinuation } \\
\hline \multicolumn{6}{|l|}{ Naïve patients } \\
\hline Jacobson et $\mathrm{al}^{8}$ & $\begin{array}{c}95 / 363 \\
104 / 364\end{array}$ & $27 \%(24 \%-31 \%)$ & $|59 / 36|$ & $44 \%(40 \%-48 \%)$ & $0.62(0.54-0.72)$ \\
\hline
\end{tabular}

Abbreviation: $\mathrm{Cl}$, confidence interval. 
Table C Direct comparison of the proportion of patients achieving a sustained virologic response, relapsing to treatment, or discontinuing treatment in the trial intervention (boceprevir provided at a dose of $800 \mathrm{mg}$ three times per day at any point during a 48-week treatment course and coadministered with pegylated interferon alpha plus ribavirin) and the trial control (matched placebo coadministered with pegylated interferon alpha plus ribavirin for 48 weeks)

\begin{tabular}{|c|c|c|c|c|c|}
\hline \multirow[t]{2}{*}{ Trial } & \multicolumn{2}{|c|}{ Intervention } & \multicolumn{2}{|c|}{ Control } & \multirow{2}{*}{$\begin{array}{c}\text { Relative risk }(95 \% \mathrm{CI}) \\
\left(\mathrm{I}^{2}[95 \% \mathrm{CI}]\right)\end{array}$} \\
\hline & $\mathbf{N}$ & $\begin{array}{l}\text { Pooled } \\
(95 \% \mathrm{CI})\end{array}$ & $\mathbf{N}$ & $\begin{array}{l}\text { Pooled } \\
(95 \% \mathrm{CI})\end{array}$ & \\
\hline \multicolumn{6}{|c|}{ Sustained virologic response } \\
\hline \multicolumn{6}{|l|}{ Naïve patients } \\
\hline \multirow[t]{4}{*}{ Kwo et $\mathrm{al}^{6}$} & $77 / 103$ & & & & \\
\hline & $69 / 103$ & \multirow{3}{*}{$62 \%(53 \%-69 \%)$} & $39 / 104$ & \multirow{3}{*}{$38 \%(33 \%-42 \%)$} & \\
\hline & $8 / 16$ & & $39 / 104$ & & $1.65(1.43-1.91)$ \\
\hline & $21 / 59$ & & & & $(48.1 \%[0 \%-77.7 \%])$ \\
\hline \multirow[t]{2}{*}{ Poordad et al ${ }^{5}$} & $242 / 366$ & & & & \\
\hline & $233 / 368$ & & $137 / 363$ & & \\
\hline \multicolumn{6}{|c|}{ Experienced patients } \\
\hline \multirow[t]{2}{*}{ Bacon et al" } & $107 / 161$ & \multirow{3}{*}{$63 \%(58 \%-68 \%)$} & & \multirow{3}{*}{$21 \%(15 \%-28 \%)$} & \\
\hline & $95 / 162$ & & $17 / 80$ & & $2.98(2.29-3.87)$ \\
\hline Flamm et al ${ }^{12}$ & $86 / 134$ & & $14 / 67$ & & $(0 \%[0 \%-/ 2.9 \%])$ \\
\hline \multicolumn{6}{|l|}{ Relapse } \\
\hline \multicolumn{6}{|l|}{ Naïve patients } \\
\hline \multirow[t]{4}{*}{ Kwo et $\mathrm{al}^{6}$} & $2 / 81$ & \multirow{6}{*}{$9 \%(6 \%-12 \%)$} & & \multirow{6}{*}{$23 \%(17 \%-28 \%)$} & \\
\hline & $5 / 76$ & & & & \\
\hline & $1 / 9$ & & $12 / 53$ & & $0.42(0.28-0.6 \mathrm{I})$ \\
\hline & $6 / 28$ & & & & $(31.7 \%[0 \%-72.2 \%])$ \\
\hline \multirow[t]{2}{*}{ Poordad et al ${ }^{5}$} & $24 / 265$ & & & & \\
\hline & $24 / 257$ & & $39 / 176$ & & \\
\hline \multicolumn{6}{|c|}{ Experienced patients } \\
\hline \multirow[t]{2}{*}{ Bacon et al" } & $|4 /| 2 \mid$ & \multirow{3}{*}{$13 \%(10 \%-17 \%)$} & זרום & \multirow{3}{*}{$33 \%(21 \%-47 \%)$} & \\
\hline & $17 / 111$ & & $8 / 25$ & & $0.40(0.26-0.62)$ \\
\hline Flamm et al ${ }^{12}$ & $11 / 95$ & & $7 / 21$ & & \\
\hline \multicolumn{6}{|l|}{ Discontinuation } \\
\hline \multicolumn{6}{|l|}{ Naïve patients } \\
\hline \multirow[t]{4}{*}{ Kwo et $\mathrm{al}^{6}$} & $27 / 103$ & & & & \\
\hline & $40 / 103$ & & & & \\
\hline & $8 / 16$ & $20 \%$ & $52 / 104$ & & $0.75(0.64-0.88)$ \\
\hline & $31 / 59$ & $39 \%(34 \%-45 \%)$ & & $54 \%(49 \%-60 \%)$ & $(54.1 \%$ [0\%-79.7\%]) \\
\hline Poordad et $\mathrm{al}^{5}$ & $151 / 366$ & & $204 / 263$ & & \\
\hline & $139 / 368$ & & $204 / 363$ & & \\
\hline Experienced patie & & & & & \\
\hline Bacon et al" & $55 / 161$ & & & & \\
\hline & $52 / 162$ & $36 \%(31 \%-41 \%)$ & $55 / 80$ & $69 \%(61 \%-76 \%)$ & $0.52(0.44-0.60)$ \\
\hline Flamm et al ${ }^{12}$ & $55 / 134$ & & $47 / 67$ & $07 \%(01 / 0-10 \%)$ & $(0 \%[0 \%-72.8 \%])$ \\
\hline
\end{tabular}

Abbreviation: $\mathrm{Cl}$, confidence interval. 
Table D Direct comparison of the proportion of patients achieving a sustained virologic response, relapsing to treatment, or discontinuing treatment in the trial intervention (telaprevir provided at a dose of $750 \mathrm{mg}$ three times per day at any point during a 48-week treatment course and coadministered with pegylated interferon alpha plus ribavirin) and the trial control (matched placebo coadministered with pegylated interferon alpha plus ribavirin for 48 weeks)

\begin{tabular}{|c|c|c|c|c|c|}
\hline \multirow[t]{2}{*}{$\overline{\text { Trial }}$} & \multicolumn{2}{|c|}{ Intervention } & \multicolumn{2}{|c|}{ Control } & \multirow{2}{*}{$\begin{array}{c}\text { Relative risk }(95 \% \mathrm{CI}) \\
\qquad\left(\mathrm{I}^{2}[95 \% \mathrm{CI}]\right)\end{array}$} \\
\hline & $\mathbf{N}$ & $\begin{array}{l}\text { Pooled } \\
(95 \% \mathrm{Cl})\end{array}$ & $\mathbf{N}$ & $\begin{array}{l}\text { Pooled } \\
(95 \% \mathrm{Cl})\end{array}$ & \\
\hline \multicolumn{6}{|c|}{ Sustained virologic response } \\
\hline \multicolumn{6}{|l|}{ Naïve patients } \\
\hline Jacobson et $\mathrm{al}^{8}$ & $\begin{array}{l}271 / 363 \\
250 / 364\end{array}$ & $71 \%(66 \%-75 \%)$ & $|58 / 36|$ & $43 \%(39 \%-48 \%)$ & \multirow[t]{2}{*}{$\begin{array}{l}\mathrm{I} .64(\mathrm{I} .50-\mathrm{I} .79) \\
(0 \%[0 \%-72.9 \%])\end{array}$} \\
\hline McHutchison et al ${ }^{9}$ & $53 / 79$ & & $31 / 75$ & & \\
\hline \multicolumn{6}{|l|}{ Experienced patients } \\
\hline McHutchison et al ${ }^{13}$ & $\begin{array}{c}171 / 266 \\
175 / 264 \\
60 / 113\end{array}$ & $62 \%(55 \%-69 \%)$ & $\begin{array}{l}22 / 132 \\
16 / 114\end{array}$ & $16 \%(11 \%-20 \%)$ & $\begin{array}{l}3.88(3.05-4.94) \\
(0 \%[0 \%-72.9 \%])\end{array}$ \\
\hline \multicolumn{6}{|l|}{ Relapse } \\
\hline \multicolumn{6}{|l|}{ Naïve patients } \\
\hline Jacobson et $\mathrm{al}^{8}$ & $\begin{array}{l}27 / 314 \\
28 / 295\end{array}$ & $9 \%(7 \%-11 \%)$ & $64 / 229$ & $29 \%(24 \%-35 \%)$ & \multirow{2}{*}{$\begin{array}{l}0.30(0.22-0.39) \\
(0 \%[0 \%-72.9 \%])\end{array}$} \\
\hline McHutchison et al ${ }^{9}$ & $3 / 51$ & & $8 / 35$ & & \\
\hline \multicolumn{6}{|l|}{ Experienced patients } \\
\hline Zeuzem et $\mathrm{al}^{14}$ & $\begin{array}{l}27 / 210 \\
26 / 204\end{array}$ & $13 \%(10 \%-16 \%)$ & $33 / 55$ & $58 \%(50 \%-66 \%)$ & $\begin{array}{l}0.22(0.17-0.29) \\
(0 \%[0 \%-72.9 \%])\end{array}$ \\
\hline \multicolumn{6}{|l|}{ Discontinuation } \\
\hline \multicolumn{6}{|l|}{ Naïve patients } \\
\hline Jacobson et $\mathrm{al}^{8}$ & $\begin{array}{c}80 / 363 \\
104 / 364\end{array}$ & $27 \%(21 \%-32 \%)$ & $|59 / 36|$ & $34 \%(15 \%-55 \%)$ & \multirow{2}{*}{$\begin{array}{c}0.75(0.45-\mid .23) \\
(84.3 \%[15.5 \%-93.0 \%])\end{array}$} \\
\hline McHutchison et al ${ }^{9}$ & $25 / 79$ & & $17 / 75$ & & \\
\hline \multicolumn{6}{|l|}{ Experienced patients } \\
\hline Zeuzem et $\mathrm{al}^{14}$ & $\begin{array}{l}100 / 266 \\
79 / 264\end{array}$ & $39 \%(29 \%-50 \%)$ & $82 / 132$ & $65 \%(59 \%-71 \%)$ & $\begin{array}{c}0.60(0.47-0.77) \\
(73.7 \%[0 \%-90.0 \%])\end{array}$ \\
\hline McHutchison et $\mathrm{al}^{13}$ & $58 / 113$ & & $78 / 114$ & & \\
\hline
\end{tabular}

Abbreviations: $\mathrm{Cl}$, confidence interval. 
Table E Direct comparison of the proportion of patients achieving a sustained virologic response, relapsing to treatment, or discontinuing treatment in the trial intervention (boceprevir provided at a dose of $800 \mathrm{mg}$ three times per day at any point during a 12-48-week treatment course and coadministered with pegylated interferon alpha plus ribavirin) and the trial control (matched placebo coadministered with pegylated interferon alpha plus ribavirin for 48 weeks)

\begin{tabular}{|c|c|c|c|c|c|}
\hline \multirow[t]{2}{*}{ Trial } & \multicolumn{2}{|c|}{ Intervention } & \multicolumn{2}{|c|}{ Control } & \multirow{2}{*}{$\begin{array}{c}\text { Relative risk }(95 \% \mathrm{CI}) \\
\qquad\left(\mathrm{I}^{2}[95 \% \mathrm{CI}]\right)\end{array}$} \\
\hline & $\mathbf{N}$ & $\begin{array}{l}\text { Pooled } \\
(95 \% \mathrm{Cl})\end{array}$ & $\mathbf{N}$ & $\begin{array}{l}\text { Pooled } \\
(95 \% \mathrm{Cl})\end{array}$ & \\
\hline \multicolumn{6}{|c|}{ Sustained virologic response } \\
\hline \multicolumn{6}{|l|}{ Naïve patients } \\
\hline \multirow[t]{6}{*}{ Kwo et $\mathrm{al}^{6}$} & $77 / 103$ & \multirow{6}{*}{$60 \%(53 \%-67 \%)$} & \multirow{5}{*}{$39 / 104$} & \multirow{8}{*}{$38 \%(33 \%-42 \%)$} & \\
\hline & $69 / 103$ & & & & \\
\hline & $8 / 16$ & & & & \\
\hline & $21 / 59$ & & & & $1.62(1.45-1.82)$ \\
\hline & $58 / 103$ & & & & $(36.6 \%[0 \%-70.8 \%])$ \\
\hline & $58 / 107$ & & & & \\
\hline \multirow[t]{2}{*}{ Poordad et al ${ }^{5}$} & $242 / 366$ & & \multirow{2}{*}{$137 / 363$} & & \\
\hline & $233 / 368$ & & & & \\
\hline \multicolumn{6}{|l|}{ Relapse } \\
\hline \multicolumn{6}{|l|}{ Naïve patients } \\
\hline \multirow[t]{6}{*}{ Kwo et $\mathrm{al}^{6}$} & $2 / 81$ & \multirow{8}{*}{$13 \%(8 \%-20 \%)$} & & \multirow{8}{*}{$23 \%(17 \%-28 \%)$} & \\
\hline & $5 / 76$ & & & & \\
\hline & $1 / 9$ & & $12 / 53$ & & \\
\hline & $6 / 28$ & & 12735 & & $0.55(0.35-0.88)$ \\
\hline & $18 / 79$ & & & & $(67.5 \%[9.6 \%-82.8 \%])$ \\
\hline & $24 / 84$ & & & & \\
\hline \multirow[t]{2}{*}{ Poordad et al ${ }^{5}$} & $24 / 265$ & & \multirow{2}{*}{$39 / 176$} & & \\
\hline & $24 / 257$ & & & & \\
\hline \multicolumn{6}{|l|}{ Discontinuation } \\
\hline \multicolumn{6}{|l|}{ Naïve patients } \\
\hline \multirow[t]{6}{*}{ Kwo et al ${ }^{6}$} & $27 / 103$ & \multirow{8}{*}{$36 \%(31 \%-42 \%)$} & & \multirow{8}{*}{$54 \%(49 \%-60 \%)$} & \\
\hline & $40 / 103$ & & & & \\
\hline & $8 / 16$ & & $52 / 104$ & & \\
\hline & $31 / 59$ & & & & $0.70(0.6 \mathrm{I}-0.82)$ \\
\hline & $27 / 103$ & & & & $(54.9 \%$ [0\%-77.8\%]) \\
\hline & $30 / 107$ & & & & \\
\hline \multirow[t]{2}{*}{ Poordad et al ${ }^{5}$} & $151 / 366$ & & \multirow{2}{*}{$204 / 363$} & & \\
\hline & $139 / 368$ & & & & \\
\hline
\end{tabular}

Abbreviation: $\mathrm{Cl}$, confidence interval. 
Table F Direct comparison of the proportion of patients achieving a sustained virologic response, relapsing to treatment, or discontinuing treatment in the trial intervention (telaprevir provided at a dose of $750 \mathrm{mg}$ three times per day at any point during a 12-48-week treatment course and coadministered with pegylated interferon alpha plus ribavirin) and the trial control (matched placebo coadministered with pegylated interferon alpha plus ribavirin for 48 weeks)

\begin{tabular}{|c|c|c|c|c|c|}
\hline \multirow[t]{2}{*}{ Trial } & \multicolumn{2}{|c|}{ Intervention } & \multicolumn{2}{|c|}{ Control } & \multirow{2}{*}{$\begin{array}{l}\text { Relative risk }(95 \% \mathrm{CI}) \\
\qquad\left(\mathrm{I}^{2}[95 \% \mathrm{CI}]\right)\end{array}$} \\
\hline & $\mathbf{N}$ & $\begin{array}{l}\text { Pooled } \\
(95 \% \mathrm{CI})\end{array}$ & $\mathbf{N}$ & $\begin{array}{l}\text { Pooled } \\
(95 \% \mathrm{Cl})\end{array}$ & \\
\hline \multicolumn{6}{|c|}{ Sustained virologic response } \\
\hline \multicolumn{6}{|l|}{ Naïve patients } \\
\hline \multirow[t]{2}{*}{ Jacobson et $\mathrm{al}^{8}$} & $271 / 363$ & & $158 / 36$ & & \\
\hline & $250 / 364$ & & (150/301 & & \\
\hline \multirow[t]{3}{*}{ McHutchison et al ${ }^{9}$} & $53 / 79$ & & & & \\
\hline & $48 / 79$ & & $31 / 75$ & & $1.57(1.45-1.69)$ \\
\hline & $6 / 17$ & $6 / \%(62 \%-/ 2 \%)$ & & $44 \%(4 \mid \%-4 / \%)$ & $(0 \%[0 \%-56.3 \%])$ \\
\hline \multirow[t]{2}{*}{ Hezode et $\mathrm{al}^{7}$} & $49 / 82$ & & $38 / 82$ & & \\
\hline & $56 / 81$ & & $38 / 82$ & & \\
\hline Kumada et $\mathrm{al}^{10}$ & $92 / 126$ & & $31 / 63$ & & \\
\hline \multicolumn{6}{|l|}{ Experienced patients } \\
\hline \multirow[t]{2}{*}{ Zeuzem et $\mathrm{al}^{14}$} & $171 / 266$ & & 221132 & & \\
\hline & $175 / 264$ & $60 \%(52 \%-67 \%)$ & 241132 & $16 \%(11 \%-20 \%)$ & $3.84(3.09-4.76)$ \\
\hline \multirow[t]{2}{*}{ McHutchison et al ${ }^{13}$} & $60 / 113$ & $60 \%(32 \%-6 / \%)$ & $16 / 114$ & & $(0 \%[0 \%-67.9 \%])$ \\
\hline & $59 / 115$ & & & & \\
\hline \multicolumn{6}{|l|}{ Relapse } \\
\hline \multicolumn{6}{|l|}{ Naïve patients } \\
\hline \multirow[t]{2}{*}{ Jacobson et $\mathrm{al}^{8}$} & $27 / 314$ & & & & \\
\hline & $28 / 295$ & & 64/229 & & \\
\hline \multirow[t]{3}{*}{ McHutchison et $\mathrm{al}^{9}$} & $3 / 51$ & & & & \\
\hline & $|/ 4|$ & & $8 / 35$ & & $0.53(0.32-0.88)$ \\
\hline & $3 / 9$ & $13 \%(8 \%-18 \%)$ & & $26 \%(22 \%-31 \%)$ & $(73 \%[31.9 \%-85.1 \%])$ \\
\hline \multirow[t]{2}{*}{ Hezode et $\mathrm{al}^{7}$} & $19 / 63$ & & $10 / 45$ & & \\
\hline & $8 / 57$ & & & & \\
\hline Kumada et al $^{10}$ & $20 / 117$ & & $11 / 49$ & & \\
\hline \multicolumn{6}{|l|}{ Experienced patients } \\
\hline \multirow[t]{2}{*}{ Zeuzem et al ${ }^{14}$} & $27 / 210$ & & & & \\
\hline & $26 / 204$ & $17 \%$ & $33 / 55$ & $57 \%(50 \%-64 \%)$ & $0.28(0.17-0.46)$ \\
\hline \multirow[t]{2}{*}{ McHutchison et al ${ }^{13}$} & $10 / 76$ & $17 \%(10 \%-24 \%)$ & $18 / 34$ & $2 / \%(30 \%-64 \%)$ & $(76.3 \%$ [0\%-89.4\%]) \\
\hline & $26 / 87$ & & $18 / 34$ & & \\
\hline \multicolumn{6}{|l|}{ Discontinuation } \\
\hline \multicolumn{6}{|l|}{ Naïve patients } \\
\hline \multirow[t]{2}{*}{ Jacobson et $\mathrm{al}^{8}$} & $95 / 363$ & & $159 / 361$ & & \\
\hline & $104 / 364$ & & 1591361 & & \\
\hline McHutchison et $\mathrm{al}^{9}$ & $25 / 79$ & & & & \\
\hline & $37 / 79$ & $28 \%(22 \%-34 \%$ & $17 / 75$ & & $0.86(0.61-1.22)$ \\
\hline & $8 / 17$ & $28 \%(22 \%-34 \%)$ & & $33 \%(2 / \%-40 \%)$ & $(84.8 \%$ [69.9\%-90.5\%]) \\
\hline Hezode et $\mathrm{al}^{7}$ & $10 / 82$ & & $32 / 82$ & & \\
\hline & $20 / 81$ & & $32 / 82$ & & \\
\hline Kumada et al ${ }^{10}$ & $27 / 126$ & & $17 / 63$ & & \\
\hline Experienced patients & & & & & \\
\hline Zeuzem et $\mathrm{al}^{14}$ & $100 / 266$ & & $82 / 132$ & & \\
\hline & $79 / 264$ & $36 \%(27 \%-45 \%)$ & & $65 \%(59 \%-71 \%)$ & $0.54(0.4 \mid-0.7 I)$ \\
\hline McHutchison et $\mathrm{al}^{13}$ & $58 / 113$ & $30 \%(27 / 0-45 \%)$ & $78 / 114$ & 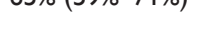 & $(80.4 \%$ [19.7\%-90.7\%]) \\
\hline & $29 / 115$ & & & & \\
\hline
\end{tabular}

Abbreviation: $\mathrm{Cl}$, confidence interval. 
Table G Adjusted indirect comparison of the proportion of patients achieving a sustained virologic response, relapsing to treatment, or discontinuing treatment at any point in a 48-week treatment course using boceprevir or telaprevir

\begin{tabular}{|c|c|c|c|c|}
\hline & Boceprevir & Telaprevir & $\begin{array}{c}\text { Relative risk } \\
(95 \% \mathrm{Cl})\end{array}$ & $P$ value \\
\hline \multicolumn{5}{|c|}{ Sustained virologic response } \\
\hline \multicolumn{5}{|l|}{ Patients } \\
\hline Naïve & $1.65(I .43-1.91)$ & $1.64(1.50-1.79)$ & $1.01(0.85-1.19)$ & 0.94 \\
\hline Experienced & $2.98(2.29-3.87)$ & $3.88(3.05-4.94)$ & $0.77(0.54-1.10)$ & 0.15 \\
\hline \multicolumn{5}{|l|}{ Relapse } \\
\hline \multicolumn{5}{|l|}{ Patients } \\
\hline Naïve & $0.42(0.28-0.6 \mathrm{I})$ & $0.30(0.22-0.39)$ & $1.40(0.86-2.28)$ & 0.18 \\
\hline Experienced & $0.40(0.26-0.62)$ & $0.22(0.17-0.29)$ & $1.82(1.09-3.03)$ & 0.02 \\
\hline \multicolumn{5}{|c|}{ Discontinuation } \\
\hline \multicolumn{5}{|l|}{ Patients } \\
\hline Naïve & $0.75(0.64-0.88)$ & $0.75(0.45-1.23)$ & $1.00(0.59-1.69)$ & 1.00 \\
\hline Experienced & $0.52(0.44-0.60)$ & $0.60(0.47-0.77)$ & $0.87(0.65-1.16)$ & 0.34 \\
\hline
\end{tabular}

Abbreviation: $\mathrm{Cl}$, confidence interval.

Table H Adjusted indirect comparison of the proportion of patients achieving a sustained virologic response, relapsing to treatment, or discontinuing treatment at any point in a 12-48-week treatment course using boceprevir or telaprevir

\begin{tabular}{|c|c|c|c|c|}
\hline & Boceprevir & Telaprevir & $\begin{array}{c}\text { Relative risk } \\
(95 \% \mathrm{Cl})\end{array}$ & $P$ value \\
\hline \multicolumn{5}{|c|}{ Sustained virologic response } \\
\hline \multicolumn{5}{|l|}{ Patients } \\
\hline Naïve & $1.62(1.45-1.82)$ & $1.57(1.45-1.69)$ & $1.06(0.92-1.21)$ & 0.41 \\
\hline Experienced & $2.98(2.29-3.87)$ & $3.84(3.09-4.76)$ & $0.78(0.55-1.09)$ & 0.14 \\
\hline \multicolumn{5}{|l|}{ Relapse } \\
\hline \multicolumn{5}{|l|}{ Patients } \\
\hline Naïve & $0.55(0.35-0.88)$ & $0.53(0.32-0.88)$ & $1.04(0.52-2.06)$ & 0.91 \\
\hline Experienced & $0.40(0.26-0.62)$ & $0.28(0.17-0.46)$ & I.43 (0.74-2.77) & 0.29 \\
\hline \multicolumn{5}{|c|}{ Discontinuation } \\
\hline \multicolumn{5}{|l|}{ Patients } \\
\hline Naïve & $0.70(0.6 \mathrm{I}-0.82)$ & $0.86(0.61-1.22)$ & $0.81(0.56-1.19)$ & 0.28 \\
\hline Experienced & $0.52(0.44-0.60)$ & $0.54(0.4 I-0.7 I)$ & $0.96(0.70-1.32)$ & 0.81 \\
\hline
\end{tabular}

Abbreviation: $\mathrm{Cl}$, confidence interval.

Table I Direct comparison of the proportion of patients achieving sustained virologic response in the trial intervention (boceprevir provided at a dose of $800 \mathrm{mg}$ three times per day during weeks 4-48 of a 48-week treatment course and coadministered with pegylated interferon alpha plus ribavirin) and the trial control (matched placebo coadministered with pegylated interferon alpha plus ribavirin for 48 weeks) among patients with compensated cirrhosis

\begin{tabular}{|c|c|c|c|c|c|}
\hline \multirow[t]{2}{*}{ Trial } & \multicolumn{2}{|c|}{ Intervention } & \multicolumn{2}{|c|}{ Control } & \multirow{2}{*}{$\begin{array}{l}\text { Relative risk } \\
\quad(95 \% \mathrm{Cl})\end{array}$} \\
\hline & $\mathbf{N}$ & $\begin{array}{l}\text { Pooled } \\
\text { (95\% Cl) }\end{array}$ & $\mathbf{N}$ & $\begin{array}{l}\text { Pooled } \\
\text { (95\% Cl) }\end{array}$ & \\
\hline \multicolumn{6}{|c|}{ Sustained virologic response } \\
\hline \multicolumn{6}{|l|}{ Naïve patients } \\
\hline Kwo et $\mathrm{al}^{6}$ & $3 / 6$ & \multirow{2}{*}{$44 \%(27 \%-61 \%)$} & $2 / 8$ & \multirow{2}{*}{$39 \%(20 \%-59 \%)$} & \multirow{2}{*}{$1.07(0.55-2.09)$} \\
\hline Poordad et al $\left.\right|^{5}$ & $10 / 24$ & & $6 / 13$ & & \\
\hline \multicolumn{6}{|c|}{ Experienced patients } \\
\hline Bacon et al" & $17 / 22$ & \multirow{2}{*}{$63 \%(37 \%-86 \%)$} & $0 / 10$ & \multirow{2}{*}{$5 \%(0.1 \%-7 \%)$} & \multirow{2}{*}{$6.91(I .46-32.6 I)$} \\
\hline Flamm et al ${ }^{12}$ & $12 / 24$ & & 1/9 & & \\
\hline
\end{tabular}

Abbreviation: $\mathrm{Cl}$, confidence interval. 
Table J Direct comparison of the proportion of patients achieving sustained virologic response in the trial intervention (telaprevir provided at a dose of $750 \mathrm{mg}$ three times per day during weeks I-I 2 of a 48-week treatment course and coadministered with pegylated interferon alpha plus ribavirin) and the trial control (matched placebo coadministered with pegylated interferon alpha plus ribavirin for 48 weeks) among patients with compensated cirrhosis

\begin{tabular}{|c|c|c|c|c|c|}
\hline \multirow[t]{2}{*}{ Trial } & \multicolumn{2}{|c|}{ Intervention } & \multicolumn{2}{|c|}{ Control } & \multirow{2}{*}{$\begin{array}{c}\text { Relative risk } \\
(95 \% \mathrm{Cl})\end{array}$} \\
\hline & $\mathbf{N}$ & $\begin{array}{l}\text { Pooled } \\
(95 \% \mathrm{Cl})\end{array}$ & $\mathbf{N}$ & $\begin{array}{l}\text { Pooled } \\
(95 \% \mathrm{Cl})\end{array}$ & \\
\hline \multicolumn{6}{|c|}{ Sustained virologic response } \\
\hline \multicolumn{6}{|l|}{ Naïve patients } \\
\hline Jacobson et $\mathrm{al}^{8}$ & $|3 / 2|$ & $61 \%(47 \%-75 \%)$ & $7 / 21$ & $34 \%(21 \%-49 \%)$ & $1.86(1.14-3.03)$ \\
\hline \multicolumn{6}{|c|}{ Experienced patients } \\
\hline Zeuzem et $\mathrm{al}^{14}$ & $77 / 119$ & $65 \%(58 \%-71 \%)$ & $6 / 59$ & $11 \%(6 \%-17 \%)$ & $6.36(3.69-10.97)$ \\
\hline
\end{tabular}

Abbreviation: $\mathrm{Cl}$, confidence interval.

Table K Adjusted indirect comparison of the proportion of compensated cirrhosis patients achieving a sustained virologic response in the boceprevir and telaprevir standard-dose durations

\begin{tabular}{|c|c|c|c|c|}
\hline Patients & Boceprevir & Telaprevir & $\begin{array}{c}\text { Relative risk } \\
(95 \% \mathrm{Cl})\end{array}$ & $P$ value \\
\hline \multicolumn{5}{|c|}{ Sustained virologic response } \\
\hline Naive & $1.07(0.55-2.09)$ & $1.86(1.14-3.03)$ & $1.73(0.70-4.28)$ & 0.33 \\
\hline Experienced & $6.91(1.46-32.61)$ & $5.84(3.25-10.50)$ & $0.84(0.16-4.44)$ & 0.36 \\
\hline
\end{tabular}

Abbreviation: $\mathrm{Cl}$, confidence interval.

Table L Direct comparison of the proportion of patients achieving sustained virologic response in the trial intervention (responseguided therapy duration boceprevir) and the trial control (matched placebo coadministered with pegylated interferon alpha plus ribavirin) among patients with compensated cirrhosis

\begin{tabular}{|c|c|c|c|c|c|}
\hline \multirow[t]{2}{*}{ Trial } & \multicolumn{2}{|c|}{ Intervention } & \multicolumn{2}{|c|}{ Control } & \multirow{2}{*}{$\begin{array}{l}\text { Relative risk } \\
(95 \% \mathrm{Cl})\end{array}$} \\
\hline & $\mathbf{N}$ & $\begin{array}{l}\text { Pooled } \\
(95 \% \mathrm{Cl})\end{array}$ & $\mathbf{N}$ & $\begin{array}{l}\text { Pooled } \\
(95 \% \mathrm{Cl})\end{array}$ & \\
\hline \multicolumn{6}{|c|}{ Sustained virologic response } \\
\hline \multicolumn{6}{|l|}{ Naïve patients } \\
\hline Poordad et al ${ }^{5}$ & $5 / 16$ & $31 \%(11 \%-59 \%)$ & $6 / 13$ & $46 \%(19 \%-75 \%)$ & $0.68(0.27-1.70)$ \\
\hline \multicolumn{6}{|c|}{ Experienced patients } \\
\hline Bacon et al" & $6 / 17$ & $35 \%(14 \%-62 \%)$ & $0 / 10$ & $0 \%$ & $7.41(1.04-52.94)$ \\
\hline
\end{tabular}

Abbreviation: $\mathrm{Cl}$, confidence interval.

Table M Direct comparison of the proportion of patients achieving sustained virologic response in the trial intervention (responseguided therapy duration telaprevir) and the trial control (matched placebo coadministered with pegylated interferon alpha plus ribavirin) among patients with compensated cirrhosis

\begin{tabular}{|c|c|c|c|c|c|}
\hline \multirow[t]{2}{*}{ Trial } & \multicolumn{2}{|c|}{ Intervention } & \multicolumn{2}{|c|}{ Control } & \multirow{2}{*}{$\begin{array}{c}\text { Relative risk } \\
(95 \% \mathrm{Cl})\end{array}$} \\
\hline & $\mathbf{N}$ & $\begin{array}{c}\text { Pooled } \\
(95 \% \mathrm{Cl})\end{array}$ & $\mathbf{N}$ & $\begin{array}{c}\text { Pooled } \\
(95 \% \mathrm{Cl})\end{array}$ & \\
\hline \multicolumn{6}{|c|}{ Sustained virologic response } \\
\hline \multicolumn{6}{|l|}{ Naïve patients } \\
\hline Jacobson et $\mathrm{al}^{8}$ & $\begin{array}{l}13 / 2 \mid \\
11 / 26\end{array}$ & $51 \%(33 \%-69 \%)$ & $7 / 21$ & $33 \%(15 \%-57 \%)$ & $1.56(0.94-2.60)$ \\
\hline
\end{tabular}

Abbreviation: $\mathrm{Cl}$, confidence interval. 
Table $\mathbf{N}$ Adjusted indirect comparison of the proportion of compensated cirrhosis patients achieving a sustained virologic response in the boceprevir and telaprevir response-guided therapy durations

\begin{tabular}{|c|c|c|c|c|}
\hline Patients & Boceprevir & Telaprevir & $\begin{array}{c}\text { Relative risk } \\
(95 \% \mathrm{Cl})\end{array}$ & $P$ value \\
\hline \multicolumn{5}{|c|}{ Sustained virologic response } \\
\hline Naive & $0.68(0.27-1.70)$ & $1.56(0.94-2.60)$ & $0.44(0.15-1.25)$ & 0.12 \\
\hline Experienced & $7.4 \mathrm{I}(1.04-52.94)$ & - & - & - \\
\hline
\end{tabular}

Abbreviation: $\mathrm{Cl}$, confidence interval.

Table $O$ Direct comparison of the proportion of patients achieving sustained virologic response in the trial intervention (boceprevir provided at a dose of $800 \mathrm{mg}$ three times per day during weeks 4-48 of a 48-week treatment course and coadministered with pegylated interferon alpha plus ribavirin) and the trial control (matched placebo coadministered with pegylated interferon alpha plus ribavirin for 48 weeks) among prior nonresponding and relapsing treatment-experienced patients

\begin{tabular}{|c|c|c|c|c|c|}
\hline \multirow[t]{2}{*}{$\overline{\text { Trial }}$} & \multicolumn{2}{|c|}{ Intervention } & \multicolumn{2}{|c|}{ Control } & \multirow{2}{*}{$\begin{array}{c}\text { Relative risk } \\
(95 \% \mathrm{Cl})\end{array}$} \\
\hline & $\mathbf{N}$ & $\begin{array}{l}\text { Pooled } \\
(95 \% \mathrm{Cl})\end{array}$ & $\mathbf{N}$ & $\begin{array}{l}\text { Pooled } \\
(95 \% \mathrm{Cl})\end{array}$ & \\
\hline \multicolumn{6}{|c|}{ Sustained virologic response } \\
\hline \multicolumn{6}{|c|}{ Prior nonresponders } \\
\hline Bacon et al" & $30 / 58$ & \multirow{2}{*}{$50 \%(40 \%-60 \%)$} & $2 / 29$ & \multirow{2}{*}{$8 \%(2 \%-17 \%)$} & \multirow{2}{*}{$8.09(2.66-24.65)$} \\
\hline Flamm et $\mathrm{al}^{12}$ & $17 / 36$ & & $1 / 20$ & & \\
\hline \multicolumn{6}{|l|}{ Prior relapsers } \\
\hline Bacon et al" & $77 / 103$ & \multirow{2}{*}{$72 \%(66 \%-78 \%)$} & $|5 / 5|$ & \multirow{2}{*}{$29 \%(21 \%-38 \%)$} & \multirow{2}{*}{$2.54(1.84-3.52)$} \\
\hline Flamm et $\mathrm{al}^{12}$ & $69 / 98$ & & $13 / 47$ & & \\
\hline
\end{tabular}

Abbreviation: $\mathrm{Cl}$, confidence interval.

Table $\mathbf{P}$ Direct comparison of the proportion of patients achieving sustained virologic response in the trial intervention (telaprevir provided at a dose of $800 \mathrm{mg}$ three times per day during weeks I-12 of a 48-week treatment course and coadministered with pegylated interferon alpha plus ribavirin) and the trial control (matched placebo coadministered with pegylated interferon alpha plus ribavirin for 48 weeks) among prior nonresponding and relapsing treatment-experienced patients

\begin{tabular}{|c|c|c|c|c|c|}
\hline \multirow[t]{2}{*}{ Trial } & \multicolumn{2}{|c|}{ Intervention } & \multicolumn{2}{|c|}{ Control } & \multirow{2}{*}{$\begin{array}{c}\text { Relative risk } \\
(95 \% \mathrm{Cl})\end{array}$} \\
\hline & $\mathbf{N}$ & $\begin{array}{l}\text { Pooled } \\
(95 \% \mathrm{Cl})\end{array}$ & $\mathbf{N}$ & $\begin{array}{l}\text { Pooled } \\
(95 \% \mathrm{Cl})\end{array}$ & \\
\hline \multicolumn{6}{|c|}{ Sustained virologic response } \\
\hline \multicolumn{6}{|c|}{ Prior nonresponders } \\
\hline Zeuzem et $\mathrm{al}^{14}$ & $50 / 121$ & $41 \%(35 \%-48 \%)$ & $6 / 64$ & $10 \%(5 \%-16 \%)$ & $4.4 I(2.52-7.7 I)$ \\
\hline \multicolumn{6}{|l|}{ Prior relapsers } \\
\hline Zeuzem et $\mathrm{al}^{14}$ & $121 / 145$ & $83 \%(79 \%-87 \%)$ & $16 / 68$ & $24 \%(17 \%-31 \%)$ & $3.55(2.6 \mathrm{I}-4.82)$ \\
\hline
\end{tabular}

Abbreviation: $\mathrm{Cl}$, confidence interval.

Table $\mathbf{Q}$ Adjusted indirect comparison of the proportion of prior nonresponding and prior relapsing patients achieving a sustained virologic response in the boceprevir and telaprevir standard-dose durations

\begin{tabular}{|c|c|c|c|c|}
\hline Patients & Boceprevir & Telaprevir & $\begin{array}{l}\text { Relative risk } \\
(95 \% \mathrm{CI})\end{array}$ & $P$ value \\
\hline \multicolumn{5}{|c|}{ Sustained virologic response } \\
\hline Prior nonresponders & $8.09(2.66-24.65)$ & $4.4 I(2.52-7.7 I)$ & $0.54(0.15-1.89)$ & 0.33 \\
\hline Prior relapsers & $2.54(1.84-3.52)$ & $3.55(2.6 \mathrm{I}-4.82)$ & $0.7 \mathrm{I}(0.45-1.1 \mathrm{I})$ & 0.14 \\
\hline
\end{tabular}

Abbreviation: $\mathrm{Cl}$, confidence interval. 
Table $\mathbf{R}$ Direct comparison of the proportion of patients achieving sustained virologic response in the response guided therapy trial intervention (response-guided boceprevir) and the trial control (matched placebo coadministered with pegylated interferon alpha plus ribavirin for 48 weeks) among prior relapsing treatment-experienced patients

\begin{tabular}{|c|c|c|c|c|c|}
\hline \multirow[t]{2}{*}{ Trial } & \multicolumn{2}{|c|}{ Intervention } & \multicolumn{2}{|c|}{ Control } & \multirow{2}{*}{$\begin{array}{l}\text { Relative risk } \\
\quad(95 \% \mathrm{Cl})\end{array}$} \\
\hline & $\mathbf{N}$ & $\begin{array}{l}\text { Pooled } \\
(95 \% \mathrm{Cl})\end{array}$ & $\mathbf{N}$ & $\begin{array}{l}\text { Pooled } \\
(95 \% \mathrm{Cl})\end{array}$ & \\
\hline \multicolumn{6}{|c|}{ Sustained virologic response } \\
\hline \multicolumn{6}{|l|}{ Prior relapsers } \\
\hline Bacon et al ${ }^{\prime \prime}$ & $23 / 57$ & $40 \%(28 \%-54 \%)$ & $2 / 29$ & $7 \%(0 \%-23 \%)$ & $5.85(|.75-2| .7 I)$ \\
\hline
\end{tabular}

Abbreviation: $\mathrm{Cl}$, confidence interval.

Table S Direct comparison of adverse events between the trial intervention (boceprevir provided at a dose of $800 \mathrm{mg}$ three times per day during weeks 4-48 of a 48-week treatment course and coadministered with pegylated interferon alpha plus ribavirin) and the trial control (matched placebo coadministered with pegylated interferon alpha plus ribavirin for 48 weeks)

\begin{tabular}{|c|c|c|c|c|c|}
\hline \multirow[t]{2}{*}{ Trial } & \multicolumn{2}{|c|}{ Intervention } & \multicolumn{2}{|c|}{ Control } & \multirow{2}{*}{$\begin{array}{c}\text { Relative risk } \\
\qquad(95 \% \mathrm{Cl})\end{array}$} \\
\hline & $\mathbf{N}$ & $\begin{array}{l}\text { Pooled } \\
(95 \% \mathrm{Cl})\end{array}$ & $\mathbf{N}$ & $\begin{array}{l}\text { Pooled } \\
(95 \% \mathrm{Cl})\end{array}$ & \\
\hline \multicolumn{6}{|l|}{ Anemia } \\
\hline \multicolumn{6}{|l|}{ Naïve patients } \\
\hline Kwo et $\mathrm{al}^{6}$ & $54 / 103$ & \multirow{2}{*}{$50 \%(45 \%-54 \%)$} & $35 / 104$ & \multirow{2}{*}{$30 \%(26 \%-35 \%)$} & \multirow{2}{*}{$1.63(1.39-1.92)$} \\
\hline Poordad et $\mathrm{al}^{5}$ & $179 / 366$ & & $107 / 363$ & & \\
\hline \multicolumn{6}{|c|}{ Experienced patients } \\
\hline Bacon et al" & $74 / 161$ & \multirow{2}{*}{$42 \%(34 \%-50 \%)$} & $16 / 80$ & \multirow{2}{*}{$34 \%(10 \%-64 \%)$} & \multirow{2}{*}{$1.30(0.42-4.03)$} \\
\hline Flamm et al ${ }^{12}$ & $50 / 134$ & & $33 / 67$ & & \\
\hline \multicolumn{6}{|l|}{ Neutropenia } \\
\hline \multicolumn{6}{|l|}{ Naïve patients } \\
\hline Kwo et $\mathrm{al}^{6}$ & $26 / 103$ & \multirow{2}{*}{$25 \%(22 \%-30 \%)$} & $12 / 104$ & \multirow{2}{*}{$17 \%(9 \%-27 \%)$} & \multirow{2}{*}{ I.5। (0.85-2.68) } \\
\hline Poordad et al $\left.\right|^{5}$ & $93 / 366$ & & $77 / 363$ & & \\
\hline \multicolumn{6}{|c|}{ Experienced patients } \\
\hline Flamm et $\mathrm{al}^{12}$ & $31 / 134$ & $23 \%(18 \%-29 \%)$ & $18 / 67$ & $27 \%(20 \%-35 \%)$ & $0.86(0.60-1.23)$ \\
\hline \multicolumn{6}{|l|}{ Rash } \\
\hline \multicolumn{6}{|l|}{ Naïve patients } \\
\hline Poordad et $\mathrm{al}^{5}$ & $88 / 366$ & $24 \%(21 \%-27 \%)$ & $83 / 363$ & $23 \%(20 \%-26 \%)$ & $1.05(0.87-1.27)$ \\
\hline \multicolumn{6}{|c|}{ Experienced patients } \\
\hline Bacon et al ${ }^{\prime \prime}$ & $22 / 161$ & \multirow{2}{*}{$15 \%(12 \%-20 \%)$} & $4 / 80$ & \multirow{2}{*}{$8 \%(3 \%-14 \%)$} & \multirow{2}{*}{$1.99(1.06-3.72)$} \\
\hline Flamm et $\mathrm{al}^{12}$ & $23 / 134$ & & $7 / 67$ & & \\
\hline \multicolumn{6}{|l|}{ Pruritus } \\
\hline \multicolumn{6}{|l|}{ Naïve patients } \\
\hline Poordad et al ${ }^{5}$ & $94 / 366$ & $26 \%(23 \%-29 \%)$ & $98 / 363$ & $27 \%(24 \%-30 \%)$ & $0.95(0.80-1.13)$ \\
\hline \multicolumn{6}{|c|}{ Experienced patients } \\
\hline Bacon et al" & $31 / 161$ & $19 \%(15 \%-24 \%)$ & $14 / 80$ & $18 \%(12 \%-24 \%)$ & $1.10(0.73-1.65)$ \\
\hline
\end{tabular}

Abbreviation: $\mathrm{Cl}$, confidence interval. 
Table T Direct comparison of adverse events between the trial intervention (telaprevir provided at a dose of $750 \mathrm{mg}$ three times per day during weeks $1-12$ of a 48-week treatment course and coadministered with pegylated interferon alpha plus ribavirin) and the trial control (matched placebo coadministered with pegylated interferon alpha plus ribavirin for 48 weeks)

\begin{tabular}{|c|c|c|c|c|c|}
\hline \multirow[t]{2}{*}{ Trial } & \multicolumn{2}{|c|}{ Intervention } & \multicolumn{2}{|c|}{ Control } & \multirow{2}{*}{$\begin{array}{c}\text { Relative risk } \\
\text { (95\% CI) }\end{array}$} \\
\hline & $\mathbf{N}$ & $\begin{array}{l}\text { Pooled } \\
\text { (95\% Cl) }\end{array}$ & $\mathbf{N}$ & $\begin{array}{l}\text { Pooled } \\
(95 \% \mathrm{Cl})\end{array}$ & \\
\hline \multicolumn{6}{|l|}{ Anemia } \\
\hline \multicolumn{6}{|l|}{ Naïve patients } \\
\hline Jacobson et $\mathrm{al}^{8}$ & $135 / 363$ & \multirow{2}{*}{$35 \%(28 \%-42 \%)$} & $70 / 361$ & \multirow{2}{*}{$22 \%(15 \%-29 \%)$} & \multirow{2}{*}{$1.51(0.88-2.61)$} \\
\hline McHutchison et al ${ }^{9}$ & $23 / 79$ & & $20 / 75$ & & \\
\hline \multicolumn{6}{|l|}{ Experienced patients } \\
\hline Zeuzem et $\mathrm{al}^{14}$ & $79 / 266$ & $30 \%(26 \%-34 \%)$ & $20 / 132$ & $15 \%(1 \mid \%-20 \%)$ & $1.96(1.43-2.68)$ \\
\hline \multicolumn{6}{|l|}{ Neutropenia } \\
\hline \multicolumn{6}{|l|}{ Naïve patients } \\
\hline Jacobson et $\mathrm{al}^{8}$ & $51 / 363$ & \multirow{2}{*}{$18 \%(10 \%-29 \%)$} & $68 / 361$ & \multirow{2}{*}{$20 \%(16 \%-24 \%)$} & \multirow{2}{*}{$0.81(0.54-1.04)$} \\
\hline McHutchison et al ${ }^{9}$ & $19 / 79$ & & $18 / 75$ & & \\
\hline \multicolumn{6}{|l|}{ Experienced patients } \\
\hline Zeuzem et $\mathrm{al}^{14}$ & $38 / 266$ & $14 \%(12 \%-18 \%)$ & $14 / 132$ & $11 \%(7 \%-15 \%)$ & $1.35(0.90-2.02)$ \\
\hline \multicolumn{6}{|l|}{ Rash } \\
\hline \multicolumn{6}{|l|}{ Naïve patients } \\
\hline Jacobson et $\mathrm{al}^{8}$ & $133 / 363$ & \multirow{2}{*}{$48 \%(26 \%-71 \%)$} & $88 / 361$ & \multirow{2}{*}{$32 \%(17 \%-49 \%)$} & \multirow{2}{*}{$1.49(1.24-1.80)$} \\
\hline McHutchison et al ${ }^{9}$ & $48 / 79$ & & $31 / 75$ & & \\
\hline \multicolumn{6}{|l|}{ Experienced patients } \\
\hline Zeuzem et $\mathrm{al}^{14}$ & $99 / 266$ & $37 \%(33 \%-41 \%)$ & $25 / 132$ & $19 \%(15 \%-24 \%)$ & $1.97(1.50-2.58)$ \\
\hline \multicolumn{6}{|l|}{ Pruritus } \\
\hline \multicolumn{6}{|l|}{ Naïve patients } \\
\hline Jacobson et $\mathrm{al}^{8}$ & $181 / 363$ & \multirow{2}{*}{$47 \%(38 \%-55 \%)$} & $|3| / 36 \mid$ & \multirow{2}{*}{$30 \%(18 \%-44 \%)$} & \multirow{2}{*}{ I.4I (I.20-I.66) } \\
\hline McHutchison et $\mathrm{al}^{9}$ & $32 / 79$ & & $17 / 75$ & & \\
\hline \multicolumn{6}{|l|}{ Experienced patients } \\
\hline Zeuzem et al ${ }^{14}$ & $138 / 266$ & $52 \%(48 \%-56 \%)$ & $36 / 132$ & $27 \%(22 \%-33 \%)$ & $1.90(1.54-2.35)$ \\
\hline
\end{tabular}

Abbreviation: $\mathrm{Cl}$, confidence interval.

Table U Direct comparison of adverse events between the trial intervention (response-guided therapy duration boceprevir) and the trial control (matched placebo coadministered with pegylated interferon alpha plus ribavirin)

\begin{tabular}{|c|c|c|c|c|c|}
\hline \multirow[t]{2}{*}{ Trial } & \multicolumn{2}{|c|}{ Intervention } & \multicolumn{2}{|c|}{ Control } & \multirow{2}{*}{$\begin{array}{c}\text { Relative risk } \\
(95 \% \mathrm{Cl})\end{array}$} \\
\hline & $\mathbf{N}$ & $\begin{array}{l}\text { Pooled } \\
(95 \% \mathrm{Cl})\end{array}$ & $\mathbf{N}$ & $\begin{array}{c}\text { Pooled } \\
(95 \% \mathrm{Cl})\end{array}$ & \\
\hline \multicolumn{6}{|l|}{ Anemia } \\
\hline \multicolumn{6}{|l|}{ Naïve patients } \\
\hline Poordad et $\mathrm{al}^{5}$ & $182 / 368$ & $49 \%(46 \%-53 \%)$ & $107 / 363$ & $30 \%(26 \%-33 \%)$ & $1.68(1.47-1.92)$ \\
\hline \multicolumn{6}{|c|}{ Experienced patients } \\
\hline Bacon et al" & $70 / 162$ & $43 \%(38 \%-49 \%)$ & $16 / 80$ & $20 \%(15 \%-27 \%)$ & $2.16(1.55-3.02)$ \\
\hline \multicolumn{6}{|l|}{ Neutropenia } \\
\hline \multicolumn{6}{|l|}{ Naïve patients } \\
\hline Poordad et $\mathrm{al}^{5}$ & $92 / 368$ & $25 \%(22 \%-28 \%)$ & $77 / 363$ & $21 \%(18 \%-24 \%)$ & I. 18 (0.98-1.42) \\
\hline \multicolumn{6}{|l|}{ Rash } \\
\hline \multicolumn{6}{|l|}{ Naïve patients } \\
\hline Poordad et $\mathrm{al}^{5}$ & $93 / 368$ & $25 \%(22 \%-29 \%)$ & $83 / 363$ & $23 \%(20 \%-26 \%)$ & I.II (0.92-I.33) \\
\hline \multicolumn{6}{|c|}{ Experienced patients } \\
\hline Bacon et al" & $27 / 162$ & $17 \%(13 \%-21 \%)$ & $4 / 80$ & $6 \%(3 \%-10 \%)$ & $3.33(1.63-6.83)$ \\
\hline \multicolumn{6}{|l|}{ Pruritus } \\
\hline \multicolumn{6}{|l|}{ Naïve patients } \\
\hline Poordad et $\mathrm{al}^{5}$ & $87 / 368$ & $24 \%(21 \%-27 \%)$ & $98 / 363$ & $27 \%(24 \%-30 \%)$ & $0.88(0.73-1.04)$ \\
\hline \multicolumn{6}{|c|}{ Experienced patients } \\
\hline Bacon et al" & $30 / 162$ & $19 \%(15 \%-23 \%)$ & $14 / 80$ & $18 \%(12 \%-24 \%)$ & $1.06(0.70-1.59)$ \\
\hline
\end{tabular}

Abbreviation: $\mathrm{Cl}$, confidence interval. 
Table V Direct comparison of adverse events between the trial intervention (response-guided therapy duration telaprevir) and the trial control (matched placebo coadministered with pegylated interferon alpha plus ribavirin)

\begin{tabular}{|c|c|c|c|c|c|}
\hline \multirow[t]{2}{*}{ Trial } & \multicolumn{2}{|c|}{ Intervention } & \multicolumn{2}{|c|}{ Control } & \multirow{2}{*}{$\begin{array}{c}\text { Relative risk } \\
(95 \% \mathrm{Cl})\end{array}$} \\
\hline & $\mathbf{N}$ & $\begin{array}{l}\text { Pooled } \\
(95 \% \mathrm{Cl})\end{array}$ & $\mathbf{N}$ & $\begin{array}{l}\text { Pooled } \\
(95 \% \mathrm{Cl})\end{array}$ & \\
\hline \multicolumn{6}{|l|}{ Anemia } \\
\hline \multicolumn{6}{|l|}{ Naïve patients } \\
\hline Jacobson et $\mathrm{al}^{8}$ & $\begin{array}{l}135 / 363 \\
|4| / 364\end{array}$ & $38 \%(35 \%-42 \%)$ & $70 / 361$ & $19 \%(17 \%-22 \%)$ & $1.96(1.64-2.33)$ \\
\hline \multicolumn{6}{|l|}{ Neutropenia } \\
\hline \multicolumn{6}{|l|}{ Naïve patients } \\
\hline Jacobson et $\mathrm{al}^{8}$ & $\begin{array}{l}51 / 363 \\
62 / 364\end{array}$ & $16 \%(13 \%-19 \%)$ & $69 / 361$ & $19 \%(16 \%-22 \%)$ & $0.81(0.65-1.02)$ \\
\hline \multicolumn{6}{|l|}{ Rash } \\
\hline \multicolumn{6}{|l|}{ Naïve patients } \\
\hline Jacobson et $\mathrm{al}^{8}$ & $\begin{array}{l}133 / 363 \\
129 / 364\end{array}$ & $36 \%(33 \%-40 \%)$ & $88 / 36 I$ & $24 \%(21 \%-28 \%)$ & $1.48(1.26-1.74)$ \\
\hline \multicolumn{6}{|l|}{ Pruritus } \\
\hline \multicolumn{6}{|l|}{ Naïve patients } \\
\hline Jacobson et $\mathrm{al}^{8}$ & $\begin{array}{l}181 / 363 \\
165 / 364\end{array}$ & $48 \%(43 \%-52 \%)$ & $|3| / 36 \mid$ & $36 \%(33 \%-40 \%)$ & $1.31(1.16-1.48)$ \\
\hline
\end{tabular}

Abbreviation: $\mathrm{Cl}$, confidence interval.

\section{Publish your work in this journal}

Therapeutics and Clinical Risk Management is an international, peerreviewed journal of clinical therapeutics and risk management, focusing on concise rapid reporting of clinical studies in all therapeutic areas, outcomes, safety, and programs for the effective, safe, and sustained use of medicines. This journal is indexed on PubMed Central, CAS,
EMBase, Scopus and the Elsevier Bibliographic databases. The manuscript management system is completely online and includes a very quick and fair peer-review system, which is all easy to use. Visit http://www.dovepress.com/testimonials.php to read real quotes from published authors.

Submit your manuscript here: http://www.dovepress.com/therapeutics-and-clinical-risk-management-journal 